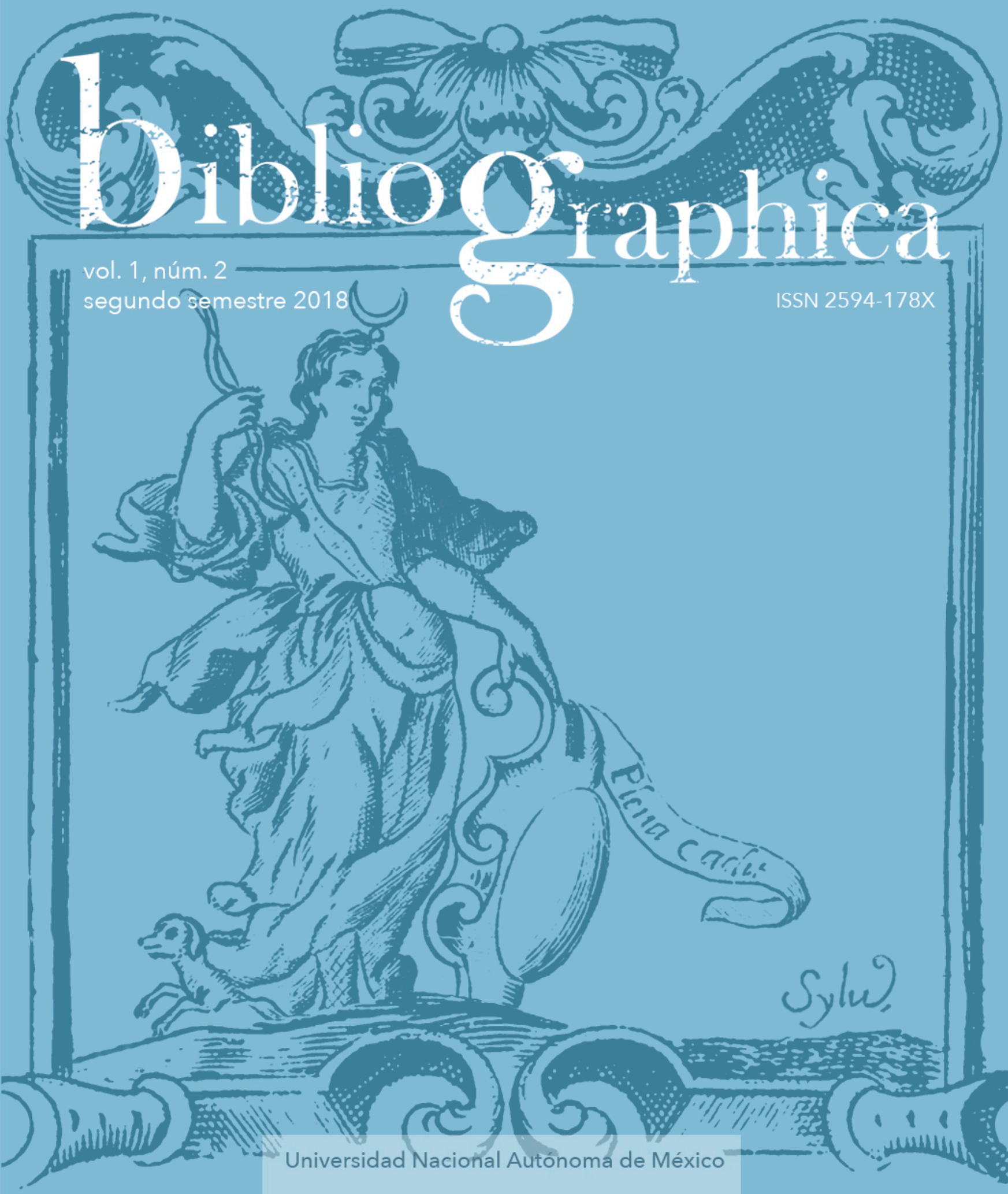




\section{bibliog graphica}

La compositio loci ignaciana

en las visiones de Vida de sor Francisca

Josefa de la Concepción (1671-1742)

The Ignatian Compositio Loci

in the Visions of Sister Francisca Josefa

de la Concepción’s Vida (1671-1742)

\section{Juan Gamilo Rojas Gómez}

Investigador independiente, Colombia 
Resumen

Palabras clave

Abstract

Keywords
Sor Francisca Josefa de la Concepción fue una monja clarisa de la ciudad de Tunja que por orden de sus confesores jesuitas escribió una autobiografía titulada Vida, en la cual describe sus visiones místicas y sueños. El artículo expone que, debido a la relación con sus confesores, su descripción de dichas visiones sigue la técnica de la compositio loci enseñada en los Ejercicios espirituales por Ignacio de Loyola. Al reconstruir su formación intelectual, caracterizar su obra como parte de la escritura conventual femenina y ejemplificarla dentro de la retórica ignaciana, este artículo constituye un estudio de caso que muestra nuevas posibilidades de analizar la cultura visual colonial en la escritura y la oralidad, trascendiendo las fronteras de lo pictórico.

Sor Francisca Josefa de la Concepción; retórica; compositio loci; visiones místicas; escritura conventual; Compañía de Jesús; Tunja.

Sister Francisca Josefa de la Concepción was a Poor Clare nun from Tunja, who wrote an autobiography known as Vida, following her Jesuit confessors' orders. In her text she described some of the mystic visions and dreams she endured. This article proposes that due to her rapport with her confessors, the description of said visions followed the compositio loci technique taught by lgnatius of Loyola in the Spiritual Exercises. Hence, tracing her intellectual education, characterizing her works among the female conventual writing genre and exemplifying it within the Ignatian rhetoric, this article is a case study that presents new possibilities of analyzing the colonial visual culture on writing and orality, surpassing pictorial boundaries.

Sister Francisca Josefa de la Concepcion; rhetoric; compositio loci; mystic visions; conventual writing; Society of Jesus; Tunja. 


\section{Introducción}

La historiografía colombiana que se ha preocupado por estudiar la cultura visual ${ }^{1}$ en el mundo colonial ha dado protagonismo a aquellas imágenes conservadas materialmente, es decir, a las pinturas, grabados y tallas que aún pueden ser vistos en el presente. La selección y definición de estos objetos coloniales como fuentes de investigación histórica se remonta a una tradición de la historia del arte que en Colombia comenzó apenas a mediados del siglo $X X^{2}$ y que sólo durante las últimas dos décadas ha empezado a ser cuestionada, incluyendo en el campo de lo visual algunos registros que habían sido catalogados patrimonio de otras corrientes historiográficas, como la historia económica y social, o de los estudios literarios.

Respecto a los últimos, la escritura conventual femenina en el Nuevo Reino de Granada ha sido objeto de investigación para historiadores y críticos literarios interesados en comprender las prácticas de lectura y escritura, así como en obtener información sobre el pasado. Sor Francisca Josefa de la Concepción, monja clarisa de Tunja más conocida como la madre Castillo, ${ }^{3}$ es un caso emblemático de este tipo de escritura en el actual territorio colombiano. Si bien no fue la primera religiosa ejemplar neogranadina de la que se tuvo noticia ni tampoco la única en escribir sus visiones místicas, ${ }^{4}$ el texto donde narró su vida sí fue el

\footnotetext{
${ }^{1}$ Este artículo forma parte de un proyecto más amplio sobre la cultura visual en el Nuevo Reino de Granada. El autor es historiador, Universidad Nacional de Colombia, sede Medellín; Magister en Historia, Universidad de los Andes. Escribió: Pintura alegórica y diferenciación social: los techos artesonados de Tunja en el siglo XVII (Bogotá: ICANH, 2017); en coautoría con Yobenj Chicangana, "El príncipe del arte nacional. Gregorio Vásquez de Arce y Ceballos interpretado por el siglo XIX", Historia Crítica 52 (2014): 205-230; "Cronología", en Yo fui pintando lo que fui viendo. Relato de un país por Débora Arango (Medellín: Museo de Arte Moderno de Medellín, 2011), 168-184, y "Hieronymus Bosch: la locura entre el pecado y el castigo", en Travesías históricas y relatos interdisciplinarios, ed. de Renzo Ramírez, Susana González y Yobenj Chicangana (Medellín: Universidad Nacional de Colombia, 2010), 33-57.

${ }^{2}$ A mediados del siglo XX, Francisco Gil Tovar, Carlos Arbeláez Camacho, Gabriel Giraldo Jaramillo y Santiago Sebastián fueron los primeros historiadores del arte que publicaron trabajos profesionales sobre pintura colonial neogranadina.

${ }^{3}$ Nacida Francisca Josefa de Castillo Toledo Guevara Niño y Rojas, ha recibido diversos nombres además del de su profesión, adicionando o sustrayendo algunos apellidos.

${ }^{4}$ A diferencia de la Vida de sor Francisca Josefa, las obras de otras religiosas fueron publicadas por sus confesores una vez que murieron, en fama de santidad, por ejemplo: fray
} 
primero en ser publicado, ${ }^{5}$ gracias a la gestión de Antonio María de Castillo y Alarcón. ${ }^{6}$ Desde ese momento y hasta el día de hoy la historia y crítica literaria han ubicado a sor Francisca Josefa en el panteón de las letras colombianas por dos razones principales. La primera de ellas se enfoca en lo que al principio fue considerado un caso atípico: una mujer clausurada en un convento que pudo escribir, aparentemente sin ninguna educación más allá de los textos que menciona en su autobiografía. El segundo motivo se relaciona con los arquetipos de identidad que estaban construyéndose en el siglo XIX, justo después de las coyunturas independentistas; en este proceso, el pasado hispánico y la fe católica jugaron un papel esencial. ${ }^{7}$ De ese modo, los fundadores de una naciente república convirtieron a la religiosa clarisa en escritora y a sus escritos espiritua-

Pedro Pablo de Villamor, Vida y virtudes de la venerable madre Francisca María del Niño Jesús, religiosa professa en el Real Convento de Carmelitas Descalzas de la Ciudad de Santa Fe (Madrid: Juan Martínez de Casas, 1723) y Pedro Andrés Calvo de la Riba, Historia de la singular vida y admirables virtudes de la venerable madre sor María Gertrudis Theresa de Santa Inés: religiosa professa en el sagrado monasterio de Santa Inès, de Monte Policiano: fundado en la ciudad de Santa Fè, del Nuevo Reyno de Granada (Madrid: Phelipe Millán, 1752). Por otro lado, hasta hace algunos años fue rescatada la autobiografía de otra clarisa que también escribió sus visiones místicas por orden de su confesor: Jerónima Nava y Saavedra, Autobiografía de una monja venerable, ed. de Ángela Inés Robledo (Cali: Universidad del Valle, 1994).

${ }^{5}$ Vida de la V. M. Francisca Josefa de la Concepción, religiosa del Convento de Sta. Clara de la ciudad de Tunja en el Nuebo Reyno de Granada. Escrita por ella misma de orden de sus confesores. Dada a luz por Don Antonio María de Castillo y Alarcón (Filadelfia: T. H. Palmer, 1817). Del manuscrito original Mi vida, MSS072, Biblioteca Luis Ángel Arango, Libros Raros y Manuscritos.

${ }^{6}$ Antonio María de Castillo y Alarcón (1782-1848) era bisnieto de Pedro Diego Antonio de Castillo y Guevara Niño, hermano de sor Francisca Josefa. Años más tarde gestionó la publicación de un segundo libro de la misma, conocido en la actualidad como Afectos espirituales. Ver: Sentimientos espirituales de la Venerable madre Francisca Josefa de la Concepción de Castillo, relijiosa en el Convento de Santa Clara de la ciudad de Tunja en la República Neo-Granadina del Sur-América: escritos por ella misma de orden de sus confesores (Santafé de Bogotá: Imprenta de Bruno Espinosa, 1843). Del manuscrito original Sentimientos espirituales, MSS071, Biblioteca Luis Ángel Arango, Libros Raros y Manuscritos. Los argumentos expuestos en el presente artículo pueden utilizarse también para comprender este último libro, que esta ocasión no será objeto de análisis.

${ }^{7}$ Caso similar es el de Gregorio Vásquez de Arce y Ceballos (1638-1711), considerado por la historia del arte colombiana como el pintor colonial más representativo y padre de las artes del país. Sobre el proceso de creación de este pintor como marcador de identidad nacional, ver Yobenj Chicangana y Juan Camilo Rojas, "El príncipe del arte nacional. Gregorio Vásquez de Arce y Ceballos interpretado por el siglo XIX", Historia Crítica 52 (2014): 205-230. 
les en obras literarias, facilitando así una amplia producción bibliográfica cuyo objetivo primordial fue ubicar a la autora en un supuesto pasado glorioso de las letras hispánicas, situándola incluso en el mismo nivel o por encima de Santa Teresa de Jesús y sor Juana Inés de la Cruz. ${ }^{8}$

El conjunto de estudios sobre la vida y obra de sor Francisca Josefa es bastante amplio y diverso. Entre las múltiples problemáticas de investigación, un primer grupo de eruditos se ha concentrado en destacar el valor literario de las obras de la religiosa tunjana, así como en reconstruir las fuentes y los orígenes literarios en autores del Siglo de Oro -tratando de ubicar a la autora en el grueso de la literatura barroca hispanoamericana-, asumiendo en repetidas ocasiones que las vivencias cotidianas contenidas en los textos son hechos históricos. ${ }^{9}$ Con base en análisis literarios, un segundo tópico consiste en rastrear las prácticas escriturarias de distintas religiosas místicas, encontrando conexiones entre los textos y demostrándose con ello ciertas prácticas de lectura y reescritura. ${ }^{10}$ Otro tema se enfoca en el misticismo y la espiritualidad

\footnotetext{
${ }^{8}$ Algunos artículos concentrados en esta comparación son Darío Achury Valenzuela, "Sor Juana Inés de la Cruz y sor Francisca Josefa de la Concepción: simpatías y diferencias", Revista del Colegio Mayor de Nuestra Señora del Rosario 67, núm. 476 (1967); Manuel Guzmán Izquierdo, "La doctora de Ávila y la doctora de Tunja", Repertorio Boyacense 35 (1947); Gustavo Otero Muñoz, "Santa Teresa y la madre Castillo", Revista de las Indias 14, núm. 43 (1942); Ernesto Porras, "Sor Juana Inés de la Cruz y sor Francisca Josefa de la Concepción: dos caminos humanos para conocer lo divino", en Memorias del Coloquio Internacional Sor Juana Inés de la Cruz y el pensamiento Novohispano (México: Instituto Mexiquense de Cultura, 1995); Alberto Villa Leiva, "La santa Teresa granadina, o la madre Josefa del Castillo", Revista Policía Nacional de Colombia 16, núm. 78 (1959). Por otra parte, se ha demostrado que algunos de los versos de sor Francisca Josefa escritos en el Cuaderno de Enciso (Libro de quentas y á de aber y de debe de Dn, loseph Enzisso, MSS073, Biblioteca Luis Ángel Arango, Libros Raros y Manuscritos) en realidad son versos transcritos del Divino Narciso de sor Juana Inés de la Cruz. Ver Alfonso Méndez Plancarte, "Un libro de Gómez Restrepo y una triple restitución a sor Juana", Ábside 7 (1941). Sobre el Cuaderno de Enciso véase Darío Achury Valenzuela, "Un manuscrito de la madre de Castillo: el llamado Cuaderno de Enciso", Boletín Cultural y Bibliográfico 19, núm. 1 (1982). 9 Darío Achury Valenzuela, Análisis crítico de los "Afectos Espirituales" de Sor Francisca Josefa de la Concepción de Castillo (Bogotá: Ministerio de Educación Nacional, 1962); sor María Antonia del Niño Jesús, Flor de santidad: la madre Castillo (Tunja: Academia Boyacense de Historia, 1993); Max Gómez Vergara, La madre Castillo (Tunja: Academia Boyacense de Historia, 1984); Elisa Mújica, Sor Francisca Josefa de Castillo (Bogotá: Procultura, 1991).

${ }^{10}$ Claudio Antoni, "A Comparative Examination of Style in the Works of Madre Castillo" (tesis doctoral, Ann Arbor University, 1982); María Teresa Morales, La madre Castillo, su espiritualidad y su estilo (Bogotá: Instituto Caro y Cuervo, 1968) y "Comparaciones y símbolos en la obra de la madre Castillo: algunas páginas de la obra La madre Castillo, su
} 
conventual a partir de los escritos de la autora. ${ }^{11}$ Un cuarto grupo de autores se ha acercado a las obras de la monja clarisa desde los estudios culturales, la teoría feminista y el psicoanálisis. ${ }^{12}$ Por último, desde la historia cultural varios autores han dedicado su atención a diversos problemas de estudio como el cuerpo, el demonio y la escatología, entre otros temas presentes en los textos de la religiosa clarisa. ${ }^{13}$

espiritualidad y su estilo", Boletín de la Academia Colombiana 22, núm. 91 (1972).

${ }^{11}$ María Teresa Cristina, "La prosa ascético-mística de sor Francisca Josefa de Castillo", en Manual de Historia de Colombia: La literatura en la Conquista y la Colonia (Bogotá: Procultura, 1982); Clara E. Herrera, Las místicas de la Nueva Granada: tres casos de búsqueda de la perfección y construcción de la santidad (Barcelona: CECAL / Paso de Barca, 2013); Ivette Hernández-Torres, "Escritura y misticismo en los Afectos espirituales de la madre Castillo", Revista Iberoamericana 69, núm. 204 (2003); Marta Cecilia Lora-Garcés, "El goce místico y la escritura en una monja de la colonia", Poligramas 22 (2005).

${ }^{12} \mathrm{Si}$ bien estos análisis resultan muy interesantes y aportan interpretaciones válidas, es frecuente encontrar en ellos una visión del pasado en la cual evidentemente hay una imposición del presente que deriva en serios anacronismos y juicios históricos. Ángela Inés Robledo, "Disociación múltiple y juegos narcisistas en Afectos y Su vida de la madre CastiIlo", Correo de los Andes 57 (1989) y "La pluralidad discursiva como mecanismo de afirmación personal en Su vida de Francisca Josefa de Castillo", en ¿Y las mujeres? Ensayos sobre literatura colombiana (Medellín: Universidad de Antioquia, 1991); Edda Cavarico, Josefo: Sor Josefa de Castillo, desde el sicoanálisis (Caldas: Ediciones Artesanales ecares, 2006); Marta Galván, "Una lectura queer en escritos de sor Juana Inés de la Cruz (1648/16511695) y madre Castillo de Tunja (1671-1742)", Cuaderno Internacional de Estudios Humanísticos 23 (2016); Stacey Schlau, "From Alienation to Consolation in Madre Castillo's Su Vida", en Women's Voices and the Politics of the Spanish Empire: From Convent Cell to Imperial Court (Nueva Orleáns: University Press of the South, 2008). Alexander Steffanell, El caso madre Castillo: discurso confesional hegemónico y canon en la literatura colombiana (Bogotá: Thomas de Quincey Editores, 2012); Si bien se incluye en esta perspectiva de los estudios de género y teoría feminista, un trabajo que es menester destacar, por la precisión de las interpretaciones y la cantidad de fuentes novedosas que incluye en su análisis, es el de Kathryn Joy McKnight, The Mystic of Tunja: The Writings of Madre Castillo 1671-1742 (Massachusetts: University of Massachusetts Press, 1997).

${ }^{13}$ Patricia Aristizábal Montes, "Locura mujer escritura: a propósito de Francisca Josefa de Castillo y Guevara", Revista de la Facultad de Ciencias Humanas y Sociales de la Universidad del Cauca 6, núm. 8 (2002); Esther Cristina Cabrera Lema, "Representaciones del demonio: miedos sociales vislumbrados en tres escritos conventuales neogranadinos", CS 9 (2012); Isabel Lara, "Erotismo, cuerpo y lenguaje en los Afectos espirituales de Francisca Josefa del Castillo" (tesis de maestría, Universidad de Calgary, 2014); Charles B. Moore, "Entre los animales y lo divino: el alma, el bestiario y el barroco en los Afectos espirituales de la madre Castillo (1672-1741)", Dieciocho 36, núm. 1 (2013) y "Fuentes y funciones de los excrementos a lo divino en Los afectos espirituales de la madre Castillo (1671-1742)", Anales de Literatura Hispanoamericana 40 (2011). 
En este artículo propongo que las descripciones de las visiones místicas y los sueños que la religiosa clarisa consignó en su autobiografía siguen estrategias retóricas cuyo objetivo era persuadir al lector, en este caso su confesor, de que aquello que allí estaba escrito era cierto, con la esperanza de convertirse en una vida ejemplar eventualmente publicable. ${ }^{14}$ La manera de lograr este propósito consistía en recrear vívidamente a través de la escritura los sucesos cotidianos de su vida al interior del convento, en especial sus experiencias místicas, de modo que pudieran ser reconstruidas en forma de imágenes en la mente de su confesor cuando fueran leídas. Estas estrategias retóricas utilizadas para formar imágenes pueden percibirse en múltiples formatos, tanto en imágenes materiales como inmateriales o efímeras, que acudían a la imaginación y al recuerdo -celebraciones religiosas y civiles, sermones, refranes, meditación y, en este caso, la escritura espiritual.

En este sentido, las visiones narradas en la Vida de sor Francisca Josefa -igual que diversos textos barrocos de Europa e Iberoamérica- están compuestas en clave retórica, específicamente siguiendo la técnica de la compositio loci que enseña san Ignacio de Loyola en los Ejercicios espirituales, con la cual estaba bastante familiarizada. El espacio, los elementos que componen las visiones y la experiencia visionaria misma están descritos en el texto con tal plasticidad que constantemente simulan la descripción ecfrástica de una pintura, si bien se trata del ejercicio inverso: construir con palabras una imagen.

En el primer apartado se caracterizará Vida como un texto ubicado dentro del corpus de la "escritura confesional barroca" y se rastreará la formación intelectual de sor Francisca Josefa de la Concepción a partir de la relación con sus confesores -todos ellos jesuitas- y de las prácticas de lectura, para proponer que estuvo en contacto con saberes teológicos y místicos que le permitieron escribir su autobiografía. En la segunda sección serán identificadas las obras

\footnotetext{
${ }^{14} \mathrm{Si}$ bien se alude a estrategias retóricas, entendidas como técnicas para persuadir, en este artículo el sentido que tiene la retórica es mucho más amplio que el de un saber para embellecer discursos o efectuar análisis literarios, de ahí que no esté enfovado en identificar figuras (sinécdoques, metonimias y metáforas, entre otras). La retórica en el mundo barroco fue una manera de comprender el mundo y producir conocimiento sobre él, una forma de pensamiento que determinó, por ejemplo, la percepción que los primeros conquistadores y evangelizadores tuvieron de los territorios americanos; que estableció las instituciones y mecanismos encargados de ordenar las sociedades y sirvió para "mover los afectos y orientar las conductas a unos particulares caminos políticos y religiosos". Fernando Rodríguez de la Flor, Mundo simbólico. Poética, política y teúrgia en el Barroco hispano (Madrid: Akal, 2012), 23.
} 
que la monja clarisa conoció -según sus propios textos y las cartas de sus confesores-, y se mostrará, en algunos apartados de Vida, cómo la técnica de la compositio loci configura las visiones en imágenes construidas a partir de las palabras escritas. Como estudio de caso, este artículo propone un texto escrito como una fuente histórica que permite comprender, por fuera pero también junto a la materialidad de la pintura o la escultura, la formación de la cultura visual del Nuevo Reino de Granada.

\section{La escritura confesional en Vida}

La primera publicación de Vida data de 1817. Sin embargo, sor Francisca Josefa empezó a escribir el manuscrito probablemente en 1713, siguiendo las órdenes de su confesor y dejándolo inacabado en 1724, de acuerdo con Achury Valenzuela. ${ }^{15}$ Las cronologías propuestas de la vida de esta monja clarisa se basan principalmente en el manuscrito de su vida, texto abundante en referencias al calendario litúrgico, pero en el que la monja no provee fechas exactas de los años cuando suceden los acontecimientos narrados. Estas cronologías han sido muy útiles para establecer rangos aproximados de los eventos descritos, pero pierden de vista que la narración se construye acudiendo a la memoria, no siempre precisa, y constantemente seleccionando aquello que, subjetivamente, es digno de ser contado: "mientras más voy escribiendo, más se me acuerdan, aún cosas que tenía sepultadas en el olvido". ${ }^{16}$ En efecto, las autobiografías operan de forma selectiva, escogiendo y dejando fuera episodios de la vida que son relevantes o fútiles, según el caso. En las autobiografías espirituales

\footnotetext{
${ }^{15}$ No existe consenso entre los biógrafos sobre la datación del manuscrito. Según sor María Antonia del Niño Jesús, las fechas abarcan de 1713 a 1724, ver: Flor de santidad, 33, 276, 280-281; para Darío Achury Valenzuela fue entre 1716 y 1724, ver: introducción a Obras completas de la madre Francisca Josefa de la Concepción de Castillo, t. 1 (Bogotá: Banco de la República, 1968), LXXXVI, CCIX; Kathryn Joy McKnight menciona que fue entre 1715 y 1721, véase The Mystic, 131. De 1713 a 1721 el confesor de sor Francisca Josefa fue el padre Juan Manuel Romero, quien se desempeñó como vicerrector del colegio y noviciado de Tunja. Su sucesor fue el padre Diego de Tapia, rector de las mismas instituciones hasta 1723. Ver: José del Rey Fajardo, Catedráticos jesuitas de la Javeriana colonial (Bogotá: Centro Editorial Javeriano, 2002), 297, 311.

${ }^{16}$ Francisca Josefa del Castillo y Guevara, Mi vida, f. 36v. El español de todas las citas del manuscrito está actualizado. Para consultar cronologías ver Achury Valenzuela, introducción; María Eugenia Hernández, "Cronología. Vida de la madre Castillo", en Madre Francisca Josefa de la Concepción de Castillo, su Vida, ed. por Ángela Inés Robledo (Caracas: Biblioteca Ayacucho, 2007); Mújica, Sor Francisca.
} 
del mundo barroco, los sucesos escogidos están relacionados con el código religioso bajo el cual se desenvuelven las vivencias, de ahí que el misticismo y el ascetismo sean protagónicos en las visiones de sor Francisca Josefa.

Por otra parte, en las autobiografías de las monjas, incluyendo la Vida, abundan los tropos o lugares comunes de las vidas de santos y de personajes ejemplares. ${ }^{17} \mathrm{La}$ infancia pecadora, la adolescencia arrepentida, el ingreso al convento sin el beneplácito familiar, las rivalidades con hermanas religiosas, el padecimiento cotidiano -siguiendo la Imitatio Christi o emulando los sufrimientos de los santos-, el llanto permanente, el aislamiento constante, la mortificación corporal, la melancolía, la adquisición de una habilidad intelectual por intervención divina -lectura, escritura, aprendizaje de latín y de teología-, las experiencias místicas, las visiones, los sueños y premoniciones, la escritura de la vida por orden del confesor o director espiritual, los deseos de parar de escribir, esconder o destruir lo que se ha escrito son todos elementos presentes en la escritura conventual femenina, siempre actualizados según el contexto, y adaptados de acuerdo a los propios intereses y experiencias individuales.

El libro está dividido en 55 capítulos y sigue el modelo de las autobiografías espirituales femeninas. En orden cronológico - por lo menos el orden que pueda evocar en su memoria- sor Francisca Josefa narra su vida al confesor (o confesores), empezando por su nacimiento y hasta unos años después de que concluye por primera vez el cargo de abadesa en 1719. El texto puede catalogarse como una vida espiritual donde, en su mayoría, la protagonista es una mujer religiosa, y podía ser escrita por ella misma o por otro sujeto, casi siempre un hombre religioso que fungió como su confesor.

Para Blanca Garí de Aguilera, los orígenes de las vidas espirituales se remontan al año 1215, cuando el IV Concilio de Letrán estableció la confesión privada y auricular como sacramento obligatorio para todos los individuos católicos en Europa. De acuerdo con esta autora, a partir de ese momento la práctica confesional se promocionó y surgió así un "espacio para hablar" sin precedentes. Pronto aparecieron manuales en los que se dictaban los métodos para exami-

${ }_{17}$ Claudio Antoni encuentra episodios similares en los textos de las vidas de Santa Catalina de Siena, Santa María Magdalena de Pazzi y sor Francisca Josefa de la Concepción. Antoni, "A Comparative Examination". Sin embargo, esos lugares comunes están presentes en las vidas y visiones de otras religiosas canonizadas, por ejemplo Las moradas de Teresa de Jesús, las Revelaciones de Gertrudis de Helfta y el Scivias de Hildegard von Bingen, al igual que en monjas como sor María de la Antigua. Dichos lugares comunes eran leídos en las vidas de los santos o escuchados en los sermones religiosos. 
narse y representarse ante el confesor, y la confesión oral no tardó demasiado en trascender el ritual sacramental para asentarse en otras prácticas, como la escritura. ${ }^{18}$

Al respecto, Manuel Peña Díaz señala que -a pesar de que cada confesión fue un suceso oral del que no se conservan registros materiales- los directores espirituales incentivaron que los fieles se sumergieran en sus conciencias, escribiendo diarios y síntesis de las vidas de cada uno. ${ }^{19}$ Así, las vidas espirituales nacieron "de la mutua experiencia de la diferencia que se dice a sí misma en el marco introspectivo de la construcción del yo en la confesión", de ahí que no tienen "un protagonista sino dos: la santa y su confesor", ${ }^{20}$ en este caso, sor Francisca Josefa de la Concepción y "Vuestra Paternidad", expresión con la que se refiere a su interlocutor a lo largo del texto. En este sentido es bastante elocuente la visión que la clarisa tunjana tiene de la confesión. En su relato los momentos más caóticos, caracterizados por tormentos demoniacos, enfermedades del cuerpo y del alma, así como los conflictos al interior del convento, sucedían ante la ausencia del confesor:

Luego Nuestro Señor me envió uno de los mayores trabajos que para mí pudo haber, y que he padecido: que fue el irse Vuestra Paternidad, y me pareció que se me caía el cielo encima y quedaba como en una noche oscura, como el que pierde su guía en un áspero camino por donde anda ciego: veía que perdía todo el amparo que podía tener en lo espiritual y temporal; parecíame que aun la luz material no veía... ${ }^{21}$

Asimismo, sólo encontraba paz cuando éste regresaba o le era asignado un nuevo confesor:

Enviaba, pues, a tiempos tan pesadas tinieblas sobre mi alma, que ninguno lo podía entender; parecíame imposible perseverar ni aun una hora, cuanto más

\footnotetext{
${ }^{18}$ Blanca Garí de Aguilera, "Vidas espirituales y prácticas de la confesión. La recepción y transmisión de la auto-biografía espiritual femenina en la Península lbérica y el Nuevo Mundo", Acta Historica et Archeologica Mediaevalia 22 (2001): 680-681.

${ }^{19}$ Manuel Peña Díaz, "Normas y transgresiones. La cultura escrita en el Siglo de Oro", en Grafías del imaginario. Representaciones culturales en España y América (siglos XVI-XVIII), comp. de Carlos Alberto González y Enriqueta Vila Vilar (México: Fondo de Cultura Económica, 2003), 128.

${ }^{20}$ Garí de Aguilera, "Vidas espirituales...", 683, 684.

${ }^{21}$ Francisca Josefa del Castillo y Guevara, Mi vida, f. 14v.
} 
toda la vida, en aquel tormento y desconsuelos. Llovían sobre mí, como lanzas, los pensamientos de aflicción y desconsuelo; la soledad era un infierno; buscar alivio en ninguna criatura, ni lo admitía ya mi corazón, ni ellas me daban lugar. No me osaba acordar de las cosas con que Nuestro Señor me había consolado, porque decía entre mí: ¡Ay, desdichada: en estas ilusiones has venido a parar, por no haber andado rectamente delante de Dios! Ponderábanse mis trabajos, acordábanse mis pecados tantos y tales, dudaba en la intención de mis obras, creía lo que decían de mí: que estaba endemoniada, que todo nacía de hipocresía y soberbia [...] quería remediar estos males, y no sabía cómo, clamaba a Nuestro Señor, y todo se volvía azote y castigo; sólo un bien hallaba seguro en mi tribulación, que era declararle a Vuestra Paternidad, como podía, mi corazón y procurar ajustarme a sus consejos, y así volvía la luz y me daba Nuestro Señor en aquel tiempo tantos deseos de ser buena, que, no obstante mi tibieza y rebeldía de mi corazón, no dejaba cosa por hacer de las que entendía ser más conformes al gusto de Dios e imitación de los santos...22

El acto de confesión se convierte entonces en recompensa de salvación. Al ser escuchada, sor Francisca Josefa se sentía comprendida y perdonada, más cerca de Cristo y, por tanto, definiéndose como un sujeto ejemplar. No debe perderse de vista que quizá éste es también otro tropo leído o escuchado en las vidas de algunos santos, un recurso retórico en el que su confesor identificaba la obediencia de la monja clarisa - uno de sus votos monásticos- y al mismo tiempo descartaba cualquier síntoma que se alejara del dogma.

Casi todos los confesores y directores espirituales que tuvo sor Francisca Josefa de la Concepción fueron jesuitas. ${ }^{23}$ Es interesante observar que esta situación no se debe a una escogencia individual, porque en Vida indica que el jesuita de turno que la escuchaba y aconsejaba cumplía la misma función con otras de sus hermanas clarisas. ${ }^{24}$ En Vida los padres de la Compañía de

\footnotetext{
22 Ibid., ff. 13r-13v.

${ }^{23}$ Por un corto periodo de tiempo tuvo un confesor franciscano porque su confesor jesuita "había perdido en este tiempo tan del todo el oído, que algunas cosas que tratábamos las oía yo referir después por el convento muy mudadas de lo que se habían dicho...", ibid., f. 44 r.

24 Desde la aprobación de la Regla de Santa Clara por el papa Inocencio IV en 1253, las clarisas han estado bajo la asistencia y dirección espiritual de los franciscanos, tal y como queda declarado en el Capítulo XII de la Regla. Si bien las reglas y constituciones han tenido muchas reformas, el vínculo con los Hermanos Menores fue siempre constante. ¿Por qué las monjas del Real Convento de Santa Clara de Tunja no tenían por directo-
} 
Jesús ("que tanto han trabajado para reducirme al camino de la verdad") ) $^{25}$ están presentes desde el nacimiento hasta el último capítulo. En efecto, dice sor Francisca Josefa:

Padeció mucho mi madre cuando yo hube de nacer al mundo, hasta que llamando a su confesor, que era el padre Diego Solano... ${ }^{26}$ para confesarse y morir, que ya no esperaba otra cosa, confesándose y teniéndose del bordón del padre, nací yo y lo que al decir esto siente mi corazón, sólo lo pudieran decir mis ojos hechos fuentes de lágrimas [...] luego aquel santo padre me bautizó y dio una grande cruz, que debía de traer consigo...27

res espirituales a los padres franciscanos? Esta situación quizá se deba a un episodio sucedido a principios del siglo XVII, cuando los padres franciscanos quisieron tomar los conventos femeninos de Santafé y Tunja, ante la negativa de dejarlos entrar libremente a la clausura femenina. El suceso alcanzó tal magnitud que incluso el expediente del caso fue enviado a España, donde se encuentra hoy en el Archivo General de Indias. Las ofensas de los franciscanos consistieron en afrentas sexuales de tipo simbólico (seducción, gestos obscenos en público) y físico. A raíz de este caso, los conventos de la rama femenina de la Orden de San Francisco quedaron bajo el gobierno del arzobispo de Santafé, en aquellos años Bartolomé Loboguerrero, muy cercano a los jesuitas. Ver Luis Miguel Córdoba Ochoa, "La toma de los conventos de la sabana por los franciscanos en 1600. Seducción, exhibición cortesana y violencia", en Caminos cruzados: cultura, imágenes e historia, comp. de Yobenj Chicangana (Medellín: Universidad Nacional de Colombia, 2010). Del mismo modo, desde la fundación del Convento de Santa Clara de Santafé de Bogotá en 1628 por el arzobispo Fernando Arias de Ugarte, quedó estipulado que el nombramiento y elección de las monjas fuese hecho por el patrón del convento (un miembro de la familia Arias de Ugarte), el arzobispo y el provincial de la Compañía de Jesús o, en su reemplazo, el rector del colegio jesuita. Véase Constanza Toquica, $A$ falta de oro: linaje, crédito y salvación. El Real Convento de Santa Clara de Santafé de Bogotá. Siglos XVII y XVIII (Bogotá: Universidad Nacional de Colombia, ICANH, 2008), 72. En la actualidad fray Ramón Salinas, OFM, es el encomendado desde el Vaticano -y ratificado por el fraile provincial de Colombia- para cumplir funciones como director espiritual de las clarisas en Colombia.

${ }^{25}$ Del Castillo y Guevara, Mi vida, f. $1 \mathrm{v}$.

${ }^{26}$ Diego Solano (1624-1685) nació en Tunja y en 1639 entró a la Compañía de Jesús en Santafé. Estudió filosofía y teología en la Universidad Javeriana. Enseñó gramática en el Colegio de Mérida y retórica en el de Tunja. Tenía amplios conocimientos de teología mística y teología moral. Escribió sermones, poemas y romances, además de la Vida ilustre en esclarecidos ejemplos de virtud de la modestisima y penitente virgen doña Antonia Cabañas, manuscrito, MR3, Biblioteca Nacional de Colombia. Ver José del Rey Fajardo, Biblioteca de escritores jesuitas neogranadinos (Bogotá: Pontificia Universidad Javeriana, 2006), 653.

27 Del Castillo y Guevara, Mi vida, f. 1v. 
La monja clarisa relata que cuando tenía 12 o 13 años su madre la llevaba junto con sus hermanos a la iglesia de la Compañía, "y en este tiempo veía yo a Vuestra Paternidad que había entrado, siendo ya sacerdote, y estando de novicio, y luego que lo veía, sentía en mi corazón una reprensión de mis locuras, una compunción y respeto tal, que luego me llenaba de temor y vergüenza, y tapaba con el manto...". ${ }^{28}$

A los 13 años su confesor era Pedro García; ${ }^{29}$ a los 14 años Pedro Calderón ${ }^{30}$ fue su padrino de confirmación. En el capítulo $V$ cuenta cómo el padre Matías de Tapia ${ }^{31}$ fue a decir la misa y a confesarla mientras estaba en el campo, fuera de Tunja. Es probable que su siguiente confesor fuera Francisco Herrera, ${ }^{32}$

\footnotetext{
${ }^{28}$ Ibid., f. 4r. No dice el nombre de su interlocutor.

29 Pedro García (ca. 1625-1697) nació en Santafé de Bogotá y entró a la Compañía en 1643. Estudió filosofía y teología en la Universidad Javeriana. En 1667 radicaba en el
} Colegio de Tunja y permaneció allí hasta su muerte. Algunos de sus textos son: Pláticas y conferencias espirituales a los Congregantes de Nuestra Señora y del Niño Jesús; Resolución de algunas dificultades que ocurren a los que caminan por la senda de la virtud y perfección, y Resolución de los casos más difíciles de moral para el uso de los /ilegible/. Todos estos manuscritos están en el Archivo Inédito Uriarte-Lecina, Universidad de Comillas en Madrid. Véase Rey Fajardo, Biblioteca de escritores..., 306-308.

${ }^{30}$ Pedro Calderón (ca. 1638-1708) nació en San Vicente de la Barquera y entró a la Compañía en 1657. Terminó su noviciado en Tunja y luego estudió filosofía y teología en la Universidad Javeriana, donde en 1672 fue profesor de esas áreas. Entre 1684 y 1688 fue rector del Colegio de Tunja. En 1696 fue nombrado provincial de Quito hasta 1700, cuando asumió ese cargo en Santafé hasta 1706, cuando ocupó el cargo de rector de la Universidad Javeriana. Escribió, entre numerosas obras, la Aprobación de Pedro Tobar y Buendía, Verdadera histórica relación del origen, manifestación y prodigiosa renovación de sí misma, y milagros de la imagen de la sacratísima Virgen María, Madre de Dios, Nuestra Señora del Rosario de Chiquinquirá (Madrid: Juan García Infanzón, 1694); De Praedestinatione, MS51, Biblioteca Nacional de Colombia (en adelante BNC), Sala de Seguridad; De scientia Dei, MS51, BNC, y Tractatus del Verbo Incarnato, MS37, BNC. Ver: Rey Fajardo, Biblioteca de escritores..., 162-167.

${ }^{31}$ Matías de Tapia (1657-1717) nació en Antioquia y entró a la Compañía en Tunja, en 1675. Hacia 1681 terminó los estudios de teología en la Universidad Javeriana. Fue misionero en el Casanare entre 1681 y 1683. En 1684 enseñaba humanidades en Santafé y en 1687 vivía en Tunja. De 1692 a 1695 fue rector del Colegio de Mérida. En 1696 era el procurador provincial del Nuevo Reino de Granada, cargo en el que pudo haber permanecido hasta 1700. Escribió: Mudo Lamento de la vastisima, y numerosa gentilidad que habita las dilatadas margenes del caudaloso Orinoco, su origen, y sus vertientes, a los piadosos oídos de la Magestad Catholica de las Españas, nuestro Señor Don Phelipe Quinto (que Dios guarde). Madrid, 1715. Véase Rey Fajardo, Biblioteca de escritores..., 663-665.

32 Francisco Herrera (ca. 1669-1709) nació en Antioquia y entró a la Compañía de Tunja en 1685. En 1691 dictaba el curso de gramática en la Universidad Javeriana. Entre 1691 
quien le encomendó escribir los Afectos espirituales; a Herrera lo sucedió Juan de Tobar, ${ }^{33}$ mientras fue rector del Colegio de Tunja. Su siguiente confesor fue Juan Martínez Rubio ${ }^{34}$ y a éste lo reemplazó Juan Manuel Romero. ${ }^{35}$ Otros jesuitas que sor Francisca Josefa tuvo como confesores fueron Mateo Mimbela, ${ }^{36}$

y 1692 se ordenó sacerdote, razón por la cual estaba en Tunja. Rector del Colegio de San Bartolomé entre 1704 y 1708. Escribió el Tractatus de Sancto Sacramento de Poenitentiae, MS94, BNC, y Tractatus de Arcano Trinitatis Misterio, manuscrito, Biblioteca Nacional de Ecuador. Del Rey Fajardo, Biblioteca de escritores..., 350-352.

33 Juan de Tobar (ca. 1644-1711) nació en Santafé y en 1668 ingresó a la Compañía en Tunja. En 1678 enseñaba gramática en el Colegio de Pamplona, y fue promovido a rector en 1691. En 1696 pasó al Colegio de Tunja a desempeñar el mismo cargo hasta 1703. Fue provincial de Quito entre 1703 y 1706, y del Nuevo Reino en 1709. Escribió: Tractatvs de charitate y Tractatus de Conscientia seu de principio interno humanorum actiorum. Rey Fajardo, Biblioteca de escritores..., 677-678.

34 Juan Martínez Rubio (1627-1709) nació en La Roda y entró a la Compañía en 1647. Probablemente llegó a América en la expedición de P. Cavero. Enseñó filosofía en la Universidad Gregoriana de Quito entre 1661 y 1664. De 1667 a 1672 fue rector del Colegio de Popayán. Hizo una primera estancia en Tunja como rector y maestro de novicios (1672-1677). Fue rector de la Universidad Javeriana (1677-1681) y más tarde provincial por primera vez, entre 1681 y 1684, cargo en el que inició las misiones del Orinoco. El segundo periodo como provincial del Nuevo Reino data de entre 1695 y 1699. Fue rector del Colegio de Tunja entre 1703 y 1709. Además de cartas y documentos administrativos, escribió relaciones sobre la Provincia del Nuevo Reino y las misiones del Orinoco. Rey Fajardo, Biblioteca de escritores..., 426-428.

35 Juan Manuel Romero (1663-1726) nació en Santafé y entró a la Compañía en Tunja, en 1679. Estudió teología en la Universidad Javeriana. En 1687 enseñaba gramática en la Javeriana y en 1692 era el responsable de las cátedras de filosofía, teología moral y teología escolástica. Entre 1713 y 1721 vivió en Tunja, donde asumió el cargo de vicerrector del colegio. Escribió el Tractatus de Peccatis, MS82, BNC. Rey Fajardo, Biblioteca de escritores..., 601-604.

${ }^{36}$ Mateo Mimbela (1663-1736) nació en Fraga y entró a la Compañía de Jesús en Tarragona, en 1677. En Zaragoza comenzó los estudios de filosofía y teología, que concluyó en Alcalá de Henares. En 1690 se ordenó como sacerdote en Sevilla y, junto con la expedición de Juan de Segovia, llegó a América ese año. Se estableció en Tunja, donde hizo su tercera probación. En 1692 enseñó teología en la Universidad Javeriana. En 1695 estuvo en las misiones del Airico. Entre 1709 y 1711 fue rector del Colegio de Tunja. Además de cartas e informes provinciales, escribió: Breve tratado del cielo y de los astros, Phisices tractatus, Tratado de Astronomía y De essentia et attributis Dei, todos ellos en la Biblioteca de la Academia Colombiana de Historia. Rey Fajardo, Biblioteca de escritores..., 466-472. 
Diego de Tapia, ${ }^{37}$ Tomás de Casabona ${ }^{38}$ y Diego de Moya. ${ }^{39}$

Como puede apreciarse, todos los confesores jesuitas que tuvo sor Francisca Josefa tenían formación en gramática, retórica, teología y filosofía, saberes contenidos en la Ratio studiorum que todos los estudiantes de los colegios de la Compañía en todo el orbe, incluyendo en Nuevo Reino de Granada, debían aprender. ${ }^{40}$ Por ello en Vida, la huella del pensamiento jesuita es evidente. Veremos que, aunado a las numerosas referencias de los Ejercicios espirituales, también alude a otros autores jesuitas cuyos libros dice sor Francisca Josefa haber leído. Diversos estudiosos de la obra de esta monja clarisa han repetido en no pocas ocasiones que el conocimiento teológico expresado en el texto fue aprendido únicamente a través de la lectura directa de ciertas fuentes. Además de las referencias en el texto, se conservan algunas cartas enviadas por sus con

${ }^{37}$ Diego de Tapia (1666-1740) nació en Medellín y entró a la Compañía de Tunja en 1683. Estudió filosofía en el Colegio de San Bartolomé y teología en la Universidad Javeriana. Entre 1691 y 1702 estuvo en las misiones del Casanare y fue profesor de gramática. Director de los colegios de Mompox entre 1702 y 1709, de Mérida 1710-1713 y luego 1715-1717, del de Tunja 1721-1723, así como rector de la Universidad Javeriana entre 1730 y 1734. Fue secretario de la Provincia entre 1716 y 1720, y provincial entre 1726 y 1730. Sobre su escritura, conocemos su correspondencia de 1724 con sor Francisca Josefa de la Concepción. Rey Fajardo, Biblioteca de escritores..., 661-663.

38 Tomás de Casabona (1678-1756) nació en Valencia y entró a la Compañía de Aragón en 1692. Cuando estudiaba teología en Barcelona pasó a Madrid esperando un traslado a América, acaecido en 1705. Fue profesor de filosofía en la Universidad Javeriana entre 1710 y 1713 . Rector y maestro de novicios en el Colegio de Tunja primero en 1724-1727 y luego entre 1733 y 1738, año en el cual fue electo provincial del Nuevo Reino, hasta 1743. Además de numerosos informes, escribió una Historia de las conquistas de españoles y descubrimiento de naciones, y reducciones de infieles en el río Orinoco, a cargo de la Religión de la Compañía, reseñada en un inventario de la biblioteca de la Provincia del Nuevo Reino que fue elaborado en 1767, a raíz de la expulsión. Véase Rey Fajardo, Biblioteca de escritores..., 184-187. También existe una carta que escribió a sor Francisca Josefa, la cual puede colegirse que es de entre junio y septiembre de 1738, por la información que ofrece sobre la elección del padre José Gumilla (1686-1750) como provincial del Nuevo Reino, Rey Fajardo, ibid., 338-347.

39 Diego de Moya (1699-1762) nació en Ubeda y entró a la Compañía en 1719, donde estudió filosofía y teología. Llegó a América en 1735 y en 1736 enseñaba teología moral en la Universidad Javeriana. Entre 1738 y 1743 fue rector del Colegio de Tunja. Se conserva una carta de 1746 dirigida a sor Francisca del Niño Jesús, sobrina de sor Francisca Josefa. Rey Fajardo, Biblioteca de escritores..., 497-498.

40 Rey Fajardo, Educadores, ascetas y empresarios. Los jesuitas en la Tunja colonial (16111767) t. I (Bogotá: Pontificia Universidad Javeriana, Academia Boyacense de Historia, 2010), 67-79. 
fesores ${ }^{41}$, documentos que mencionan otras obras de jesuitas que posiblemente aquellos pudieron haberle prestado. La relación que sor Francisca Josefa mantuvo con sus confesores -quienes interpretaban sus visiones-, ha sido subestimada por los investigadores. A partir de esa comunicación epistolar y oral -confesional, de la cual no se tiene ningún registro material-, al igual que de la lectura directa de textos, la escucha de sermones en la Iglesia y la percepción de imágenes religiosas puede comprenderse cómo adquirió todos los saberes sobre mística, ascética y teología perceptibles en sus textos.

Debe tenerse en cuenta que las prácticas de lectura en el temprano mundo moderno tenían otras dinámicas, en las cuales lo colectivo y lo oral jugaban un papel esencial. Tal y como indica Rosalva Loreto, circulaban en los claustros distintos tipos de textos impresos que eran leídos en lugares donde se reunía el colectivo de la comunidad, bien sea el noviciado, el refectorio o las salas de labores. En estos espacios, la lectura de impresos se hacía obligatoriamente en voz alta, y los textos impresos y manuscritos eran copiados a mano repetidas ocasiones, circulando también de ese modo; para acercarse a los textos, en los conventos la dinámica consistía en la lectura, la escucha y la memorización. ${ }^{42}$

Al respecto, las pocas referencias que se tienen sobre regulación de la lectura en los conventos en el Nuevo Reino de Granada provienen de las reglas y constituciones. Como se indica en la Ordenación XX de la Regla de las clarisas de Santafé:

Todas las religiosas, serán solícitas en acudir al Refectorio, tañida la Campana, y hallarse han presentes a la bendición de la Mesa, y entren en él con compostura, y reverencia, y no se vaya ninguna, sin haber dado las gracias. Y entre tanto que comen, una de las Religiosas, lea un libro santo, y devoto, que por la Abadesa, y Vicaria, se le señalara, y esto sea todos los días, y noches, sin exceptuar ningunos... ${ }^{43}$

\footnotetext{
${ }^{41}$ De la comunicación epistolar entre sor Francisca Josefa de la Concepción y sus confesores sólo se conservan las cartas que ellos le enviaron. Estos documentos están agrupados en el manuscrito de los Sentimientos espirituales.

42 Rosalva Loreto, "Leer, contar, cantar y escribir. Un acercamiento a las prácticas de la lectura conventual. Puebla de los Ángeles, México, siglos XVII y XVIII", Estudios de Historia Novohispana 23 (2000); 68-69, 76.

${ }^{43}$ Regla, constituciones y ordenaciones de las religiosas de S. Clara, de la ciudad de S. Fee de Bogotá: en el nuevo Reyno de Granada: de las Indias de el Peru (Roma: Lucas Antonio Chracas, 1699), 176. Esta misma regla fue aceptada por las clarisas de Pamplona, pero se desconoce si también la adoptaron las de Tunja, o si ellas tuvieron una propia. En todo
} 
Más adelante, en la Ordenación XXVII, se encuentra otra referencia a la lectura en voz alta:

Sean Cuidadosas, y solícitas, todas las dichas Religiosas, a acudir a la hora de oración mental, así a la mañana antes de amanecer: como lo tienen de loable costumbre, de que se siguen muchos provechos Espirituales, leyéndose un punto, por la Religiosa, que se señalara, por la Madre Abadesa. Y así mismo, después de Completas, en la misma forma, lo cual por ninguna cosa que se ofrezca, se deje de hacer, por ser la oración mental, el Riego del Cielo, con que las Almas producen nuevas flores de virtudes y conservan las que tienen. ${ }^{44}$

La lectura conventual era entonces, siguiendo a Antonio Castillo, una función restringida, ritual y vigilada que, de ese modo, sometía la interpretación $-y$, por tanto, la apropiación- de aquello que era leído. ${ }^{45}$ Por su parte, Dominique Julia señala que las disposiciones tridentinas establecieron una relación más viva dentro de la comunidad: a los clérigos correspondía la predicación a los fieles y la relación individual de la confesión, y a los seglares la recepción de una voz autorizada que les permitía apropiarse de la palabra divina, pues "Para internarse por el camino de la santidad no era necesario tener un acceso directo a los textos sagrados". ${ }^{46}$

En efecto, es bien distinto ser el propietario de un libro que ser su lector. De hecho, que con frecuencia los libros no aparezcan en los inventarios de los conventos no significa que los miembros de las comunidades religiosas no pudiesen acceder al conocimiento teológico y espiritual. En ese periodo ocurre, en palabras de León Carlos Álvarez, un deslizamiento entre lo escrito y lo oral que funde la letra y la palabra, el hablante y el libro, y el acto de leer con la audición. ${ }^{47}$ Siendo así, ¿qué tan plausible es pensar que el manuscrito de sor Fran-

caso, como abadesa, sor Francisca Josefa de la Concepción tuvo que conocer las reglas de la orden. En la historiografía colombiana no hay trabajos publicados o inéditos sobre las prácticas de lectura en el Nuevo Reino de Granada. Los ejemplos en este artículo provienen de contextos históricos cercanos como España, Nueva España y Perú.

44 Ibid., 198-199.

${ }^{45}$ Antonio Castillo, "Leer en comunidad. Libro y espiritualidad en la España del Barroco", Via Spiritus 7 (2000): 117-118.

${ }^{46}$ Dominique Julia, "Lecturas y Contrarreforma", en Historia de la lectura en el mundo occidental, dir. de Guglielmo Cavallo y Roger Chartier (Madrid: Taurus, 1997), 367.

${ }^{47}$ León Carlos Álvarez Santaló, "Algunos usos del libro y la escritura en el ámbito conventual: el 'Desengaño de religiosos' de sor María de la Antigua (1614-1617)", en Grafías del imaginario. Representaciones culturales en España y América (siglos XVI-XVIII), comp. por 
cisca Josefa también fuera leído de ese modo después de su muerte? Como indicamos, la difusión de los textos no dependía necesariamente de que estuvieran impresos. ${ }^{48}$ Su manuscrito pudo ser leído por otras monjas después de su muerte, de ahí que luego se le considerara ejemplar entre el resto de las clarisas de Tunja. ${ }^{49}$ Además, sabemos que los papeles que iba escribiendo eran leídos por los jesuitas, quienes los hacían circular entre ellos, por ello podemos afirmar que se tenía noticia de sor Francisca Josefa por fuera del convento.

Uno de los confesores que tuvo en su poder el manuscrito de los Afectos espirituales fue el padre Francisco de Herrera quien, antes de morir en Santafé, lo entregó a Diego de Tapia, solicitándole que lo devolviera a la monja clarisa. ${ }^{50}$ Cuando murió Herrera en 1709 lo reemplazó Mateo Mimbela, y sólo hasta 1721 Diego de Tapia fue confesor de sor Francisca Josefa. Si esta noticia es cierta, y teniendo en cuenta que desconocemos la inmediatez con que Tapia devolvió los manuscritos a su propietaria, se intuye que pudieron haber estado en su poder incluso 12 años. ¿Qué sucedió con esos escritos durante ese tiempo? ¿Por quiénes fueron leídos? ¿Cómo fueron interpretados? ¿Qué tan público se hizo el conocimiento de la vida de esta monja?

El capítulo XIX inicia con una certeza de sor Francisca Josefa: "Padre mío: si no fuera porque Vuestra Paternidad me lo manda, y sólo es quien lo ha de ver, y no llegara a noticia de otro, no sé yo cómo pudiera animarme a decir estas cosas; y más lo que ahora diré, que es de mucho recelo acertar a entenderme,

Carlos Alberto González y Enriqueta Vila Vilar (México: FCE, 2003), 197.

${ }^{48} \mathrm{Si}$ bien en otro contexto, un trabajo que muestra muy bien cómo el conocimiento circulaba por otras vías distintas al texto impreso es el de Fernando Bouza, Corre manuscrito: una historia cultural del Siglo de Oro (Madrid: Marcial Pons, 2001).

${ }^{49}$ Los manuscritos estuvieron en el Real Convento de Santa Clara hasta que Antonio María de Castillo empezó gestiones para publicarlos en 1813. Además de sor Francisca Josefa, otros miembros de su familia estuvieron en el Real Convento de Santa Clara de Tunja: su madre ingresó cuando enviudó, y enfermo y murió profesa en el convento. Su hermana Juana de Castillo y Guevara también ingresó cuando enviudó en 1703. Su hermano Pedro Diego Antonio de Castillo y Guevara tuvo seis hijas y todas ellas fueron monjas clarisas. Su otra hermana, Catalina Lugarda de Castillo y Guevara, tuvo una hija, Josefa de Mesa y Castillo, quien ingresó al convento de las clarisas en 1706. Asimismo, sor Francisca Josefa era tataranieta de Catalina de Sanabria, hermana de Juana Macías de Figueroa, fundadora del Real Convento de Santa Clara de Tunja. Quizá las intenciones de comenzar el proceso están relacionadas con todas estas redes de parentesco que pretendían incrementar el honor familiar.

50 Noticia que presenta Achury Valenzuela, introducción, CXCV. En el capítulo XXIX señala que Francisco de Herrera los devolvió a "Vuestra Paternidad", pero no indica el nombre del interlocutor. Del Castillo y Guevara, Vida, f. 54v. 
o darme a entender". ${ }^{51}$ Es probable que se trate de un recurso retórico utilizado por la visionaria tunjana -así como los constantes deseos de quemar lo escrito-, lo cual denunciaría su conocimiento de las intenciones de sus confesores para eventualmente reescribir su vida con base en su manuscrito, y convertirla en una figura ejemplar. Sor Francisca Josefa estaba bastante familiarizada con las vidas de santos; dice haber leído la vida de las carmelitas santa Teresa de Jesús y santa María Magdalena de Pazzi, por lo que conoce la relación de estas monjas con sus confesores, así como las posteriores vidas escritas por ellos. Rosalva Loreto señala que, basados en las autobiografías espirituales, los confesores reescribían los textos con un doble objetivo: hacer pública la existencia de la vida ejemplar e iniciar o promover la causa de beatificación de las religiosas ante la Sagrada Congregación de Ritos en el Vaticano. ${ }^{52}$

En el caso de sor Francisca Josefa, cuatro años después de su muerte, el último de sus confesores, el padre Diego de Moya, escribió una carta a sor Francisca del Niño Jesús, sobrina de la clarisa muerta. Este documento es bastante elocuente respecto a las intenciones que se tenían sobre el conocimiento público de la vida de sor Francisca Josefa. Moya inicia solicitando el secreto absoluto del contenido de la carta: "El asunto de esta carta sólo es de mí para Vuestra Reverencia no más; pues lo profiero con la calidad de un total sigilo, porque no conviene corra yo por inventor o autor del caso: en esta presuposición, pues, escribo, y de que me notificará Vuestra Reverencia que de sus mismas manos pasó al fuego esta carta...." ${ }^{53}$

Como indica el documento, las intenciones de Moya consisten en publicar el sermón fúnebre que pronunció cuando murió la monja clarisa, mientras que el propósito de la sobrina era que se escribiera la vida de sor Francisca Josefa. De Moya asegura que con la publicación del sermón "se excitan los deseos de las gentes en orden a procurar que su vida salga impresa, y al paso que esta la desearon, después, cuando ya la ven a los ojos, la buscan con mayor afición, para utilizarse de sus ejemplos, como acaeció con la Azucena de Quito, ${ }^{54}$ pues corriendo por Lima y otras regiones el sermón de sus honras, suspiraban todos por el libro de su vida...." ${ }^{55}$ En su opinión, la eficacia retórica

\footnotetext{
51 lbid., f. 29r.

${ }^{52}$ Loreto, "Leer, contar...", 92.

${ }^{53}$ Del Castillo y Guevara, Sentimientos espirituales, f. 17 r.

${ }^{54}$ Se refiere a santa Mariana de Jesús, terciaria franciscana más cercana a los jesuitas de Quito.

${ }^{55}$ Del Castillo y Guevara, Sentimientos..., ff. 17r-17v.
} 
de los sermones fúnebres publicados consiste en que incentivarían la escritura de una vida completa en forma de libro:

que entretenga de presente los afectos, y, por otra parte, fije los ejemplos en la estimación, para que siempre estimulen a imitarlos, alienten a los fervorosos, confundan a los tibios, despierten a los dormidos en el olvido de la eternidad; de donde también resulta que, encomendándose a la que ven tan favorecida de Dios, condescendiendo el cielo a tales clamores, comience a esclarecerla con prodigios, que suele obrar por su intercesión, con que después se podrá enriquecer su vida; mayormente si en el título del sermón impreso se advierte que su venerable cuerpo quedó tratable en la muerte, y después de un año de enterrado se halló incorrupto y flexible; porque con estas noticias se animan a pedir por sus méritos a Dios muchos particulares beneficios. Fuera de que mucho tiene lo que en el sermón se dice, qué imitar de virtudes, qué tomar de penitencias, qué procurar de heroica santidad, qué desear de subida oración, qué seguir de estrechez y retiro, qué abrazar de desprecio del mundo, qué pretender de amor a Dios, qué aplaudir de divinos favores, como Vuestra Reverencia con lágrimas, la comunidad con sollozos, el pueblo con admiraciones, y lo más granado, así religioso como eclesiástico y civil, con ternuras, mostró universalmente el día de las honras... ${ }^{56}$

La carta de Moya no fue quemada ni destruida por sor Francisca del Niño Jesús. El sermón no fue publicado y no ha sido encontrada la versión manuscrita. Ningún jesuita escribió tampoco la vida de sor Francisca Josefa, pero sí es evidente que había intenciones de seguir el proceso desde el momento en que murió. La vida espiritual, escrita por ella misma, fue publicada sólo 75 años después; de haber sido publicada con anterioridad, las descripciones místicas hubiesen sido leídas en clave espiritual y ejemplarizante y no en clave literaria, como sucedió ya en el siglo XIX cuando fue elevada al panteón de las letras y no al de la mística. El contenido de la vida se hubiera convertido en un modelo -la verosimilitud histórica no era puesta en duda- que esperaba ordenar el cuerpo social, conduciéndolo por el camino de las virtudes de sor Francisca Josefa y del rechazo a los vicios ofrecidos por el demonio en las visiones. El relato de la monja hubiera sido un tratado edificante en el que además, la protagonista formaba parte de la comunidad que lo estaba leyendo. En esa lectura, las imágenes de

${ }^{56}$ Ibid., f. 17v. 
las visiones y los episodios de las vidas hubieran sido descritos retóricamente con el propósito de que el lector se persuadiera de que aquello que estaba leyendo era cierto, y para que su voluntad tratara de imitar ese modelo virtuoso.

\section{Retórica ignaciana en las visiones de Vida}

Las referencias a los Ejercicios espirituales son recurrentes en la autobiografía de sor Francisca Josefa de la Concepción. En el capítulo Ill cuenta cómo una hermana de su papá, también religiosa del Real Convento de Santa Clara de Tunja, la previno de leer comedias y le regaló "dos libritos de meditaciones de mi padre san Ignacio". ${ }^{57}$ En adelante, las oportunidades de "hacer los ejercicios de mi padre san Ignacio" fueron bastantes frecuentes, "Pues como en los ejercicios fortaleciera mi alma y me diera luz de muchas cosas". Además de practicarlos, los enseñaba. Cuando la nombraron maestra de novicias en varias ocasiones, dice que entraba con ellas en ejercicios, llamando la atención del confesor particularmente sobre una novicia muy rebelde que quería "volverse al siglo, mas fue Nuestro Señor servido que entrando en ejercicios, se desengañó".

No obstante, los Ejercicios espirituales no fueron las únicas fuentes de meditación que sor Francisca Josefa conoció. Se sabe por Vida, los Sentimientos espirituales y la correspondencia con sus confesores, cuáles autores y qué obras conocía. La más citada y quizá la más importante para ella fue la Biblia, esencialmente el Antiguo Testamento, ${ }^{58}$ así como el Breviarum Romanum. ${ }^{59}$ Por otra parte, en Vida cuenta que su madre le leía las Fundaciones de Santa Teresa, que leyó a Molina, ${ }^{60}$ a Osuna, ${ }^{61}$ alguna de las vidas de santa María Magdalena de

\footnotetext{
${ }^{57}$ Del Castillo y Guevara, Vida, f. 4v.

${ }^{58}$ En su mayoría, las locuciones latinas presentes en Vida provienen de la Vulgata: Samuel, I Macabeos, Job, Salmos, Eclesiastés, Sabiduría, Eclesiástico, Isaías, Jeremías, Lamentaciones, Oseas y Habacuc. Sin embargo, también hay textos en latín tomados del Nuevo Testamento: Mateo, Romanos, II Corintios, Efesios, I Timoteo y I Juan.

${ }^{59}$ La Sala de Libros Raros y Manuscritos de la Biblioteca Luis Ángel Arango conserva una edición de 1693 que fue propiedad de sor Francisca Josefa de la Concepción.

60 Antonio de Molina, Exercicios espirituales de las excelencias, provecho, y necessidad de la oracion mental, reduzidas a dotrina y meditaciones: sacados de los Santos Padres y Dotores de la Iglesia (Burgos: Juan Baptista Varessio, 1615). Hay ediciones posteriores.

${ }^{61}$ Quizá conoció alguna de las seis partes del Abecedario espiritual: Primera parte (Sevilla: Juan Cromberger, 1528), Segunda parte (Sevilla: Juan Varela, 1530), Tercera parte (Toledo: Remón de Petras, 1527), Cuarta parte (Sevilla: [s. n., s. f.]), Quinta parte (Burgos: Juan de Junta, 1542) y Sexta parte (Medina del Campo: Mateo y Francisco del Canto, 1554).
} 
Pazzi62 y un libro de "nuestra señora de la Manta". ${ }^{63}$ Adicionalmente, las cartas que sus confesores le escribieron mencionan De Religione del padre Suárez, ${ }^{64}$ los Sentimientos del venerable padre La Puente, ${ }^{65}$ y el beato Juan de la Cruz. ${ }^{66}$ Asimismo, María Antonia del Niño Dios afirma que en la Biblioteca del Convento de Santa Clara reposa un libro de Nieremberg con una anotación manuscrita que consigna que perteneció a sor Francisca Josefa. ${ }^{67}$

Vemos que fue determinante en su formación la presencia de manuales de oración y meditación. Esos manuales promueven un tipo de oración en clave retórica, donde la imitación de la Pasión de Cristo y del sufrimiento de los santos son esenciales a modo de camino purgativo para la salvación. Afirma Carlos Alberto González, estos manuales ascético-espirituales hacen partícipes a los sujetos para moverlos a la devoción; la manera de lograrlo parte de la imaginación concreta de escenas como si se las tuviera "delante de los ojos", como si se estuviese allí presente para causar reacciones emotivas como el arrepentimiento, miedo, la obediencia y piedad. ${ }^{68}$ Ese "delante de los ojos" es un recurso explotado por la retórica ignaciana nacida en los Ejercicios espirituales, pero con unos orígenes bastante lejanos. ${ }^{69}$

A través de la oración mental, los Ejercicios permiten una comunicación directa de la fe, del dogma, con el lector. Las oraciones están completamente establecidas, cerrando la posibilidad de que los fieles imaginen interpreta-

\footnotetext{
${ }^{62}$ La primera biografía de esta monja carmelita fue escrita por Vincenzo Puccini en 1609 y la tradujo Juan Bautista de Leza como Vida de la Bienaventurada, y Extatica Virgen Maria Magdalena de Pazzi (Roma: Vital Mascardo, 1648).

${ }^{63}$ Quizá se refiere al libro sobre la virgen de Chiquinquirá, de Pedro Tobar y Buendía, anteriormente citado, cuya Aprobación fue escrita por Pedro Calderón, uno de los confesores de sor Francisca Josefa.

${ }^{64}$ En la carta, el confesor anónimo habla del tomo segundo. Francisco Suárez, De religione (Lyon: Jacobo Cardon, 1630).

${ }^{65}$ Luis de La Puente, Sentimientos y avisos espirituales (Sevilla: Juan de Ossuna, 1671).

${ }^{66}$ Por las referencias en el texto, podría tratarse de la Subida al Monte Carmelo y el Cántico espiritual, de los que hay diversas ediciones.

${ }^{67}$ Juan Eusebio Nieremberg, De la devoción y patrocinio de San Miguel, príncipe de los ángeles (Madrid: María de Quiñones, 1643). Véase sor María Antonia del Niño Jesús, Flor de santidad, 279.

${ }^{68}$ Carlos Alberto González, "'Lection espiritual'. Lectores y lectura en los libros ascéticoespirituales de la Contrarreforma", en Grafías del imaginario. Representaciones culturales en España y América (siglos XVI-XVIII), comp. de Carlos Alberto González y Enriqueta Vila Vilar (México: FCE, 2003), 284.

${ }^{69}$ Sobre los ejercicios espirituales en la Antigüedad grecolatina, ver Pierre Hadot, Ejercicios espirituales y filosofía antigua (Madrid: Siruela, 2006).
} 
ciones posibles de la Pasión de Cristo, por poner un ejemplo. De acuerdo con Fernando Rodríguez de la Flor, los Ejercicios promueven una oración mental sistemática en concordancia con el "imperialismo" de la imagen que la Contrarreforma difundió; son "un procedimiento visual de orden interno para forjar escenas mnemotécnicas, compuestas, por lo tanto, de loci y de imagines, que puedan estar ancladas a la realidad figurativa o que pueden tener un carácter más abstracto". ${ }^{70}$ En esa meditación visual que san Ignacio propone está presente una técnica denominada compositio loci o composición de lugar. Como el propósito inicial de los Ejercicios es la meditación y la oración mental, se trata de reconstruir con la imaginación el espacio o lugar donde sucede la escena o episodio sobre el que se reflexiona (Juicio Final, Transfiguración, Natividad).

Dice san Ignacio:

El primer preámbulo es composición viendo el lugar. Aquí es de notar que en la contemplación o meditación visible, la composición será ver con la vista de la imaginación el lugar corpóreo donde se halla la cosa que quiero contemplar. Digo el lugar corpóreo así como un templo o monte, donde se halla Jesu Christo o Nuestra Señora, según lo que quiero contemplar. En la invisible, como es aquí de los pecados, la composición será ver con la vista imaginativa y considerar mi ánima ser encarcerada en este cuerpo corruptible y todo el compósito en este valle, como desterrado entre brutos animales... ${ }^{71}$

Es entonces una estrategia mental para crear imágenes que reconstruyen espacialmente el dogma. Aquí se hace uso de la imagen para acceder a Dios, es el conocido modo catafático o modo de vía afirmativa que consiste en expresar a través de imágenes el conocimiento de Dios. ${ }^{72}$ Según va ordenando san Ignacio a través de cada una de las cuatro semanas de los Ejercicios, se trata de reconstruir mentalmente la vida de Cristo en secuencias narrativas que se remontan a la Creación y concluyen en la Resurrección. Sor Francisca Josefa sigue el mismo método en su oración, pero también lo traslada a la escritura. En Vida, los sue-

70 Rodríguez de la Flor, Emblemas. Lecturas de la imagen simbólica (Madrid: Alianza, 1995), 147. Las cursivas son del autor del libro.

${ }^{71}$ Ignacio de Loyola, Obras completas (Madrid: Biblioteca de Autores Cristianos, 1963), 209-210.

72 El otro método es el apofático o modo de vía negativa, que recurre a la negación de toda referencia a Dios que no sea la unión mística misma. Véase Iveta Nakládalová, "Contemplar a Dios sin imágenes. La imagen en los tratados de meditación en la Primera Edad Moderna", Studia Aurea 9 (2015): 281. 
ños, visiones místicas, trances y premoniciones, así como episodios cotidianos al interior del convento, son descritos siguiendo la técnica de manera que el lector lleve "delante de los ojos", "con la vista de la imaginación", lo que ella está narrando. La primera descripción que construye con estas estrategias sucede cuando era una niña:

Pues el temor que digo despertaba Nuestro Señor en mí, algunas noches en sueños veía cosas espantosas. En una ocasión me pareció andar sobre un entresuelo hecho de ladrillos, puestos punta con punta, como en el aire, y con gran peligro, y mirando abajo veía un río de fuego, negro y horrible, y que entre él andaban tantas serpientes, sapos y culebras, como caras y brazos de hombres que se veían sumidos en aquel pozo o río; yo desperté con gran llanto, y por la mañana vi que en las extremidades de los dedos y las uñas tenía señales del fuego; aunque yo esto no pude saber cómo sería. Otra vez, me hallaba en un valle tan dilatado, tan profundo, de una oscuridad tan penosa, cual no se sabe decir ni ponderar, y al cabo de él estaba un pozo horrible de fuego negro y espeso; a la orilla andaban los espíritus malos haciendo y dando varios modos de tormentos a diferentes hombres, conforme a sus vicios. Con estas cosas y otras me avisaba Dios misericordioso, para que no le ofendiera, del castigo y pena de los malos; mas nada de esto bastó para que yo no cometiera muchas culpas, aun en aquella edad. ${ }^{73}$

La escena descrita en el sueño - pesadilla- se concentra en dos elementos: primero, el espacio está descrito con tal detalle, como si se tratara de una descripción ecfrástica de una imagen, pero el ejercicio es precisamente el contrario: las palabras configuran en la mente del lector una imagen tan fiel que lo convierten en espectador del suceso narrado. Por otra parte, están los personajes que habitan el espacio, criaturas repugnantes antítesis de lo que ella representa. Acá se trata de mover la voluntad del lector a un camino del bien como precaución de un panorama de condena, justo en una sociedad barroca organizada a partir de la dicotomía vicios-virtudes. Es interesante observar que las visiones que tienen más recursos retóricos de tipo visual, aquellas que hacen más figurativa la visión a partir de la lectura son las relacionadas con el tormento, el espacio lúgubre, lo pecaminoso y lo infernal:

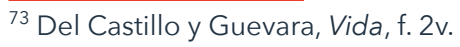


Entré en fin, o me hizo entrar el Señor Dios mío omnipotente, en aquella tierra tenebrosa, cubierta de oscuridad de la muerte, tierra de toda miseria, donde habitan las sombras de la muerte, donde no había más orden que un sempiterno horror. El temor y el temor [sic] vinieron sobre mí, y las tinieblas me tejieron un apretado y lóbrego capuz, los lazos de la muerte y los dolores del infierno me cercaron. Toda la composición interior de mi alma, y aun la exterior, me parece, del cuerpo, se descompuso. Parece que dio mi Señor permiso a aquellos leones infernales para que extremaran el rigor de sus furias; y parece que abrió el pozo sobre mí su boca, y me sorbió el profundo de todos los males en un solo mal, que era verme a mí misma (a lo que entendía) separada del Sumo Bien, y entregada al sumo mal; no porque sintiera ni tuviera inclinación al vicio, antes tanto horror a ellos, cuanto no se puede explicar; y entre aquel pavor y asombro, me parecía que estaba cercada de todos cuantos pecados puede haber en el mundo o maquinarse en el infierno. Y pues en las cosas que pasan en el alma, no soy yo capaz de explicarlas ni de entenderlas, diré algunos efectos que me causaban. ${ }^{74}$

La estrategia consiste en acudir a una descripción vívida, experimentable en la contemplación mental del lector, de un paisaje de condena, como consecuencia del alejamiento del camino de la virtud. Dichos aspectos sólo pueden percibirse esencialmente a través de la visión (oscuridad, sombras, tinieblas), elementos cuya presencia también se hace efectiva a través de este sentido (capuz, leones, pozo, pecados personificados) y acciones que implican observación (separación del cuerpo y del alma, ingesta del pozo) son descritos con tal detalle que la escena sólo puede ser experimentada visualmente. Esa descripción vívida fue un recurso retórico utilizado ya desde la antigüedad grecolatina por Aristóteles, Cicerón y Quintiliano: la hipotiposis, enargeia o evidentia ${ }^{75}$. Mediante una selección específica de las palabras se construye una imagen con tal fidelidad que "más parece que se percibe con los ojos que con los oídos", ${ }^{76}$ esperando mover de manera efectiva las emociones del auditorio, en el caso de la palabra pronunciada, por ejemplo, en un sermón. ${ }^{77}$ La hipotiposis cons-

\footnotetext{
74 lbid., f. 98 r.

75 Heinrich Plett, Enargeia in Classical Antiquity and the Early Modern Age (Leiden: Brill, 2012), 12.

76 Quintiliano, Instituciones oratorias, t. II (Madrid: Perlado Páez y Compañía, 1916), 93.

77 Este tipo de técnica fue usado también por los predicadores y misioneros para que el ejercicio de imaginación mental pudiera llegar a un grupo más amplio de individuos a
} 
tituye una ilustración en la cual aquello que es fielmente representado se hace presente. ${ }^{78}$

Si bien la compositio loci ignaciana fue diseñada como ejercicio mental, muy pronto esta técnica de meditación barroca, determinada por los saberes de la retórica, expandió sus fronteras hacia la predicación y la escritura. En ese transcurso, la hipotiposis resultó determinante para que el proceso de imaginación y persuasión fuese efectivo: a través de la escucha y lectura, las imágenes pueden percibirse de manera inmediata y presencial, haciéndose virtualmente posible todo lo que el orador o escritor en "su mente ha pensado y planeado, de modo que es capaz de empujar al auditorio a donde se lo propone". ${ }^{79}$ En Vida es común que sor Francisca Josefa entre en contacto con santos como lgnacio (le entrega la comunión), Magdalena de Pazzi (la consuela) y Francisco (la cuestiona), entre otros. Asimismo, goza de la cercanía de Cristo, viéndose a sí misma, como en una narración en tercera persona, comprometida y protagónica dentro del locus donde se desenvuelve la escena:

Un día, en la oración, me parece se recogía mi alma, no sé cómo, y veía a mí misma, que andaba por un camino muy áspero, en compañía de Nuestro Señor; yo llevaba un bordón que me ayudaba a pasar los pasos dificultosos, y estribaba en él; a un lado y otro del camino había grandes árboles, y yo entendía de Nuestro Señor que si me faltara aquel bordón, sería fácil para Su Majestad acomodarme otro, y en faltando éste, otro, y otro, de aquellos árboles, y que

través del sermón escuchado. Reconstruyendo de manera "espectacular" episodios de la Pasión o augurando la condena en el infierno, se reforzaba la piedad cristiana. Francisco Luis Rico Callado, "Conversión y persuasión en el barroco: propuestas para el estudio de las misiones interiores en la España postridentina", Studia Historica: Historia Moderna 24 (2002): 363-386.

${ }^{78}$ Rodolphe Gasché, "Hipotiposis", Revista de Humanidades 22 (2010): 214.

79 Cicerón, Sobre el orador (Madrid: Gredos, 2002), 397. A propósito de esta cita, fue la obra de este autor clásico la que más influenció a los jesuitas para componer sus tratados de retórica. El libro del jesuita portugués Cipriano Soares, De arte rhetorica libri tres ex Aristoteles, Cicerone e Quintiliano (Coimbra: loannem Barrerium, 1562), tuvo un total de 135 ediciones hasta 1792, convirtiéndose en la obra de retórica más influyente en la enseñanza de este arte en los colegios de la Compañía. Ver: Peter Mack, A History of Renaissance Rhetoric 1380-1620 (Oxford: Oxford University Press, 2011), 176-177; Rey Fajardo, La república de las letras en la Venezuela colonial (la enseñanza de las humanidades en los colegios jesuíticos) (Caracas: Academia Nacional de Historia, 2007), 190. Quizá con este libro se formaron los jesuitas del Colegio de la Compañía de Tunja, quienes además predicaron sermones que pudo haber escuchado sor Francisca Josefa de la Concepción. 
lo cortaría y haría a medida de mi necesidad, y llegando a un paso, u hoyo profundo, me parecía que Nuestro Señor, pasando a la otra parte, me daba la mano para pasar de allí. ${ }^{80}$

Se trata de una visión bastante afable y esperanzadora, una experiencia mística donde recorre un camino difícil ayudada por Cristo, su marido. Pero resulta interesante ver cómo en esta ocasión -así como en muchas otras a lo largo del texto-, a través de la expresión "veía a mí misma" -"veíame", escribe también-, además de ser la narradora y protagonista, es también espectadora del evento descrito. Es común que en estas oportunidades en las que su personaje se bifurca, se desdobla, recurra a las visiones más emotivas, donde lo emocional y lo sensitivo envuelven la descripción retórica. En una experiencia menos cálida con Cristo, escribe:

me hallé en un lugar del convento con Nuestro Señor crucificado vivo, y en el aire los brazos, sin haber cosa en que los sustentara: estaba como agonizando con grandes angustias, y yo llegaba a mantenerle los brazos con los míos, teniendo con mis manos, las suyas, lo cual hacía con grande trabajo, aunque con grande ánimo y consuelo, porque me parecía que aliviaba la fatiga y tormento con que Nuestro Señor se mostraba, hasta que al cabo de algún tiempo me hallaba sentada, y que Nuestro Señor caía muerto sobre mí, y yo le cubría con mi mantellina... ${ }^{81}$

En esta visión vuelve a presentarse en tercera persona, sosteniendo el cuerpo yacente de Cristo -recreando un motivo iconográfico bastante prolífico en el mundo barroco ${ }^{82}$, la Piedad- e incorporándose en el cuerpo de María al hacer una descripción visual de la experiencia visionaria aún más efectiva. Si bien, como se ha mostrado, la compositio loci ignaciana sirve para construir imágenes mentales en la meditación -así como en la oratoria y escritura-, para traer a los ojos de la imaginación figuras que conducen a los fieles por el camino de la virtud, los otros sentidos también están comprometidos en la

80 lbid., ff. 14v-15r. El énfasis es mío.

81 Ibid., f. 68v. El énfasis es mío.

${ }^{82}$ Asunción Lavrín propone que las imágenes pictóricas y escultóricas estuvieron siempre presentes en los conventos femeninos des de la Edad Media, proporcionando información a las monjas, por lo cual no es extraño que las descripciones de las visiones místicas posean elementos icónicos. Asunción Lavrín, Las esposas de Cristo. La vida conventual en la Nueva España (México: FCE, 2016), 152. 
experiencia retórica, pero siempre en función de apoyar la construcción visual. Los lamentos de los condenados son escuchados, el olor del azufre asfixia y la sensación de calor o frío se hace insoportable en la visión del Infierno. Dice san Ignacio al respecto:

1. ${ }^{\circ}$ puncto. El primer puncto será ver con la vista de la imaginación los grandes fuegos, y las ánimas como en cuerpos ígneos.

2. ${ }^{\circ}$ El 2. ${ }^{\circ}$ : oír con las orejas llantos, alaridos, voces, blasfemias contra Christo nuestro Señor y contra todos sus santos.

3. ${ }^{\circ}$ El 3.': oler con el olfato humo, piedra azufre, sentina y cosas pútridas.

$4 .^{\circ}$ El $4 .^{\circ}$ : gustar con el gusto cosas amargas, así como lágrimas, tristezas y el verme de la consciencia.

5..$^{\circ}$ El 5. ${ }^{\circ}$ tocar con el tacto, es a saber, cómo los fuegos tocan y abrasan las ánimas. ${ }^{83}$

Se comprende entonces que la eficacia de la experiencia depende del conjunto de los sentidos, donde los estímulos visuales, olfativos o auditivos se cruzan y generan respuestas que no son necesariamente visuales, olfativas o auditivas, respectivamente. De tal manera, los Ejercicios promueven una sinestesia barroca en la que el estímulo visual -pictórico- podría generar una experiencia olfativa. A nivel textual, sor Francisca Josefa describe en sus visiones otras experiencias sensoriales que no son estrictamente visuales, si bien el lector recurre a la imaginación para visualizarlas:

Este fue permitirle Nuestro Señor al enemigo que me afligiera con representarme cuantas herejías e infidelidades se han inventado entre los hombres; y sin cesar todo el día en cualquiera ocupación que tuviera, sonaban aquellos silbos de la serpiente infernal en los oídos de mi alma, con tanta sutileza y astucia, tornándome a su propósito cuanto veía, oía y leía, que solo en la malicia y condenada astucia de Satanás cabía. En recogiéndome a oración, retirada a buscar a mi Dios, escondido entre noche tan oscura y temerosa, me daba un modo de sueño; que aun puesta de rodillas estaba como emborrachada o medio fuera de mí, y parece que cuantos herejes, o los que los enseñaron, que son los enemigos malos, daban voces en mis oídos relatando sus sectas, herejías

${ }^{83}$ Loyola, Obras, 214. 
y maldades; y aquello me parece sonaba en los oídos del cuerpo y dejaba así aturdida la cabeza como atormentada el alma... ${ }^{84}$

Este entrecruzamiento de experiencias sensoriales reunidas en la descripción vívida de la experiencia visionaria, como indicamos, estaba determinado por la técnica de la compositio loci ignaciana. De acuerdo con Fernando Rodríguez de la Flor, esta técnica de meditación permite estratificar las imágenes mentales "en escenas inmutables [...] expresivas de toda una historia subyacente, y que una vez codificadas pueden ser sepultadas en la MEMORIA y ser extraídas ('demanda') del fondo de la misma con una cierta periodicidad". ${ }^{85}$

En efecto, sor Francisca Josefa pertenecía a una sociedad donde el conocimiento circulaba esencialmente de manera oral; allí las estrategias para recordar eran incentivadas a través de diversos mecanismos como la compositio loci, pero también la emblemática ${ }^{86}$ y las imágenes materiales. Como sostiene Alfonso Mendiola, "la lógica figurativa elabora imágenes que ayudan a la transmisión del conocimiento (de la cultura) en una sociedad donde el acceso a los libros no es fácil". ${ }^{87} \mathrm{Y}$ es precisamente en estas circunstancias cuando la visualización de una imagen a partir de un recurso retórico como la hipotiposis, se hace efectiva: provocando en la mente del lector o auditor el acceso a sus experiencias del pasado gracias a la memoria - haber escuchado un sermón, haber visto una imagen-, pero también generando nuevas experiencias gracias a la imaginación. ${ }^{88}$ Todas las imágenes inaprensibles, configuradas en la mente, imaginativamente en la oración, la visión mística o el sueño, se transmutan en la escritura para ser reconfiguradas mentalmente y "ante los ojos", en el acto de la lectura. Sor Francisca Josefa vio sus imágenes "con los ojos del alma" y sus confesores con los ojos de la memoria y la imaginación, porque ambos compartían ese mismo código de interpretación del mundo barroco que era la retórica.

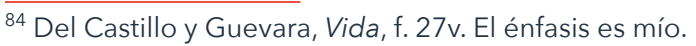

${ }^{85}$ Rodríguez de la Flor, Teatro de la Memoria. Siete ensayos sobre mnemotécnica española de los siglos XVII y XVIII (Valladolid: Junta de Castilla y León, 1988), 84.

${ }^{86} \mathrm{Al}$ respecto, las visiones de sor Francisca Josefa están en una suerte de contrapunto con libros de emblemistas jesuitas, las Adnotationis et meditationes in Evangelia de Jerónimo Nadal y la Pia desideria de Hugo Herman, así como con libros ilustrados que seguían la obra de san Ignacio, por ejemplo la Práctica de los ejercicios espirituales de Sebastián Izquierdo.

87 Alfonso Mendiola, Retórica, comunicación y realidad. La construcción retórica de las batallas en las crónicas de la Conquista (México: Universidad Iberoamericana, 2003), 162. 88 María Ema Llorente, "La visualización como vehículo de la comunicación poética", Adversus XIV, núm. 32 (2017): 108. 
"Contemplatio humana secundum statum presentis vitae, non potest esse absque phantasmatibus", 89 le escribe un confesor anónimo a sor Francisca Josefa en una de las cartas. Con esta declaración le indica que el "modo de meditar con figuras, o internas o externas, es también admirable, y el más común en la extática virgen Santa Teresa", 90 monja que sor Francisca Josefa intenta emular a lo largo de Vida. Y continúa, como director espiritual, persuadiéndola de que "nos servimos de ellas [las imágenes] como de medios y pasos para ir a Dios, sin parar en ellas, como quien está mirando con gran gusto las estrellas por el anteojo de larga vista, no atiende al anteojo sino a las estrellas. Y así prosiga en este modo de oración, que la ha de unir estrechamente con Dios". ${ }^{\prime 1}$ Con esta metáfora escópica comprendemos que las visiones místicas de sor Francisca Josefa, mediatizadas en la escritura, forman parte de una tecnología visual barroca en la que la imagen, en todas sus formas posibles, sirve como soporte de la representación del mundo.

Representar pictóricamente una visión, dice Víctor Stoichita, significa hacer visible un fenómeno interior, y el espectador de esa representación pictórica se convierte en testigo del acto de visión, necesario para demostrar la realidad visible del acto visionario. ${ }^{92}$ Los términos pintura y espectador pueden también ser reemplazados por escritura y lector, discurso y auditor, por experiencia y sujeto barroco. A 300 años de la escritura de Vida, la relación con la imagen es otra muy diferente a la actual. Parafraseando a Georges Didi-Huberman, la autora y el lector de Vida no están ante las imágenes allí descritas, están dentro de ellas. ${ }^{93}$ En la lectura de los manuscritos por parte de los confesores jesuitas, la imagen adquiere una naturaleza virtual que presentifica -traslatio temporum - la experiencia, permitiéndoles atestiguar que aquello que allí estaba siendo narrado, era cierto. Hoy, el texto parece aludir a una extrañeza literaria.

89 Del Castillo y Guevara, Sentimientos espirituales, f. 14r. La frase fue tomada de santo Tomás de Aquino, Suma teológica, Secunda secundae, CLXXX, V, II. Podría traducirse como: "La contemplación humana, de acuerdo al estado de la vida actual, no es posible sin imágenes".

90 Ibid., El énfasis es mío.

91 lbid., ff. 14r-14v.

${ }^{2}$ Victor Stoichita, El ojo místico. Pintura y visión religiosa en el Siglo de Oro español (Madrid: Alianza, 1995), 183-184.

${ }^{93}$ Georges Didi-Huberman, Ante la imagen. Pregunta formulada a los fines de una historia del arte (Murcia: CENDEAC, 2010), 205. 


\section{Consideraciones finales}

Hay un espacio bastante amplio entre las lecturas -individuales, confesionales o colectivas- de sor Francisca Josefa de la Concepción y los textos que ella escribió. Es por eso que, si bien es útil rastrear en sus textos las fuentes literarias que conoció, allí no se resuelve el problema de la lectura y la escritura. Afirmar que la monja tunjana extrajo conocimiento místico de esta o aquella obra literaria, como si de estrictos análisis iconográficos se tratara, no es más útil que reconocer que en una sociedad de tradición oral, tanto el impreso y el manuscrito leídos como la palabra escuchada y la imagen vista tienen el mismo origen, presente en todos los ámbitos culturales del orbe católico. Tal es el caso de muchas religiosas hispanoamericanas que escribieron sus vidas espirituales: la lectura directa de fuentes, la lectura colectiva en voz alta, la conversación con sus confesores -en la que son recreadas experiencias visuales a nivel oral-, la escucha de sermones y la observación de imágenes religiosas con las cuales convivían diariamente fueron todos los elementos de ese circuito barroco que configuró una cultura visual presente en sus textos.

En efecto, las visiones místicas del Juicio Final, por mencionar un ejemplo, como las imágenes pictóricas que representan -auguran- el mismo episodio, tenían una fuente en común: el dogma católico que circulaba en distintos formatos y era apropiado de diferentes maneras. ¿Hasta qué punto los estudios literarios, en su recurrente propósito de identificar las visiones con fuentes literarias específicas -reduciendo la autoría a la copia y no a la apropiación-, se convierten en un espacio positivista que quiere racionalizar la experiencia mística transfigurada en texto? Místicas o no, lo visto con los ojos del alma encuentra su lugar en un modo de ser en el mundo, corresponde a una cosmovisión específica de alcances planetarios: el barroco hispánico.

Al mostrar la relación directa de sor Francisca Josefa de la Concepción con algunos miembros de la intelligentia de la Compañía de Jesús -quienes funcionaron como sus directores espirituales- en la ciudad de Tunja durante los siglos XVII y XVIII se establecen unos demarcados vínculos de pensamiento evidenciados en su escritura.

Cabe aclarar que al estudiar dicha relación no se pretende desmentir la existencia real de las visiones místicas de la monja clarisa, sino proponer que en el texto las descripciones de sus visiones, apariciones, premoniciones y sueños se configuran siguiendo el mismo método de la compositio loci propuesto por Ignacio de Loyola en los Ejercicios espirituales, obra con la que estaba tan familia- 
rizada. Asimismo, la utilización de recursos como la hipotiposis evidencia un conocimiento retórico que no fue aprendido necesariamente estudiando la preceptiva -como sí lo hicieron los jesuitas en su periodo de formación-, pero sí escuchando a los predicadores y formando imágenes vívidas a partir de las palabras.

¿Cómo estudiar entonces lo visual en estos textos? Evidentemente hay una frontera temporal que separa la mirada del investigador actual de la del lector barroco, así como es distinto el interés de ambos al acercarse a esos textos. Las imágenes mentales que puedan formarse con la lectura de Vida difieren en uno y otro, bien sea porque son diversas la cultura visual, la formación o las esperanzas de cada uno. En el siglo XVIII pudo haber tantas imágenes de las visiones como lectores del texto -si bien el propósito de la contemplación ignaciana era establecer una y sólo una forma de reflexionar sobre el dogma católico-, del mismo modo que en el siglo XXI hay tantas interpretaciones como investigadores posibles. Sin embargo este tipo de fuentes, en las que lo textual parece relucir por encima de lo icónico, solicitan análisis de investigadores interesados en estudiar lo visual en el mundo colonial hispanoamericano, análisis que no se reduzcan a valores estéticos de lo literario y artístico, sino que se proyecten en distintos campos y exploren interpretaciones culturales de las sociedades barrocas.

\section{Fuentes consultadas}

Achury Valenzuela, Darío. Análisis crítico de los "Afectos Espirituales" de sor Francisca Josefa de la Concepción de Castillo. Bogotá: Ministerio de Educación Nacional, 1962.

Achury Valenzuela, Darío. "Sor Juana Inés de la Cruz y sor Francisca Josefa de la Concepción: simpatías y diferencias". Revista del Colegio Mayor de Nuestra Señora del Rosario 67, núm. 476 (1967): 228-232.

Achury Valenzuela, Darío. Introducción a Obras completas de la madre Francisca Josefa de la Concepción de Castillo, t. I, VII-CCXVI. Bogotá: Banco de la República, 1968.

Achury Valenzuela, Darío. "Un manuscrito de la madre de Castillo: el Ilamado Cuaderno de Enciso". Boletín Cultural y Bibliográfico 19, núm. 1 (1982): 47-86.

Álvarez Santaló, León Carlos. "Algunos usos del libro y la escritura en el ámbito conventual: el 'Desengaño de religiosos' de sor María de la Antigua (16141617)". En Grafías del imaginario. Representaciones culturales en España y América (siglos XVI-XVIII). Comp. de Carlos Alberto González y Enriqueta 
Vila Vilar, 157-202. México: Fondo de Cultura Económica, 2003.

Aristizábal Montes, Patricia. "Locura mujer escritura: a propósito de Francisca Josefa de Castillo y Guevara". Revista de la Facultad de Ciencias Humanas y Sociales de la Universidad del Cauca 6, núm. 8 (2002): 9-18.

Bouza, Fernando. Corre manuscrito: una historia cultural del Siglo de Oro. Madrid: Marcial Pons, 2001.

Cabrera Lema, Esther Cristina. "Representaciones del demonio: miedos sociales vislumbrados en tres escritos conventuales neogranadinos". CS 9 (2012): 89-114.

Castillo, Antonio. "Leer en comunidad. Libro y espiritualidad en la España del Barroco". Via Spiritus 7 (2000): 99-122.

Castillo y Guevara, Francisca Josefa del. Mi vida. Manuscrito, MSS072, Biblioteca Luis Ángel Arango, Libros Raros y Manuscritos.

Castillo y Guevara, Francisca Josefa del. Sentimientos espirituales. MSS071, Biblioteca Luis Ángel Arango, Libros Raros y Manuscritos.

Cavarico, Edda. Josefo: Sor Josefa de Castillo, desde el sicoanálisis. Caldas: Ediciones Artesanales ECARES, 2006.

Chicangana, Yobenj y Juan Camilo Rojas. "El príncipe del arte nacional. Gregorio Vásquez de Arce y Ceballos interpretado por el siglo XIX". Historia Crítica 52 (2014): 205-230.

Cicerón, Marco Tulio. Sobre el orador. Madrid: Gredos, 2002.

Córdoba Ochoa, Luis Miguel. "La toma de los conventos de la sabana por los franciscanos en 1600. Seducción, exhibición cortesana y violencia". En Caminos cruzados: cultura, imágenes e historia. Comp. de Yobenj Chicangana, 159-177. Medellín: Universidad Nacional de Colombia, 2010.

Cristina, María Teresa. "La prosa ascético-mística de sor Francisca Josefa de Castillo". En Manual de Historia de Colombia: La literatura en la Conquista y la Colonia, 559-567. Bogotá: Procultura, 1982.

Didi-Huberman, Georges. Ante la imagen. Pregunta formulada a los fines de una historia del arte. Murcia: CENDEAC, 2010.

Galván, Marta. "Una lectura queer en escritos de sor Juana Inés de la Cruz (1648/1651-1695) y madre Castillo de Tunja (1671-1742)". Cuaderno Internacional de Estudios Humanísticos 23 (2016): 120-129.

Garí de Aguilera, Blanca. "Vidas espirituales y prácticas de la confesión. La recepción y transmisión de la auto-biografía espiritual femenina en la Península Ibérica y el Nuevo Mundo". Acta Historica et Archeologica Mediaevalia 22 (2001): 679-696. 
Gasché, Rodolphe. "Hipotiposis". Revista de Humanidades 22 (2010): 207-228.

Gómez Vergara, Max. La madre Castillo. Tunja: Academia Boyacense de Historia, 1984.

González, Carlos Alberto. "'Lection espiritual'. Lectores y lectura en los libros ascético-espirituales de la Contrarreforma". En Grafías del imaginario. Representaciones culturales en España y América (siglos XVI-XVIII). Comp. de Carlos Alberto González y Enriqueta Vila Vilar, 272-300. México: FCE, 2003.

Guzmán Izquierdo, Manuel. "La doctora de Ávila y la doctora de Tunja". Repertorio Boyacense 35 (1947): 1789-1792.

Hadot, Pierre. Ejercicios espirituales y filosofía antigua. Madrid: Siruela, 2006.

Hernández, María Eugenia. "Cronología. Vida de la madre Castillo". En Madre Francisca Josefa de la Concepción de Castillo. Su vida. Ed. de Ángela Inés Robledo, 283-341. Caracas: Biblioteca Ayacucho, 2007.

Hernández-Torres, Ivette. "Escritura y misticismo en los Afectos espirituales de la madre Castillo". Revista Iberoamericana 69, núm. 204 (2003): 653-665.

Herrera, Clara E. Las místicas de la Nueva Granada: tres casos de búsqueda de la perfección y construcción de la santidad. Barcelona: CECAL / Paso de Barca, 2013.

Julia, Dominique. "Lecturas y Contrarreforma". En Historia de la lectura en el mundo occidental. Dir. de Guglielmo Cavallo y Roger Chartier, 367-412. Madrid: Taurus, 1997.

Lara, Isabel. "Erotismo, cuerpo y lenguaje en los Afectos espirituales de Francisca Josefa del Castillo". Tesis de maestría. Universidad de Calgary, 2014.

Lavrín, Asunción. Las esposas de Cristo. La vida conventual en la Nueva España. México: FCE, 2016.

Llorente, María Ema. "La visualización como vehículo de la comunicación poética". Adversus 14, núm. 32 (2017): 103-116.

Lora-Garcés, Marta Cecilia. "El goce místico y la escritura en una monja de la colonia". Poligramas 22 (2005): 21-40.

Loreto, Rosalva. "Leer, contar, cantar y escribir. Un acercamiento a las prácticas de la lectura conventual. Puebla de los Ángeles, México, siglos XVII y XVIII". Estudios de Historia Novohispana 23 (2000): 67-95.

Loyola, Ignacio de. Obras completas. Madrid: Biblioteca de Autores Cristianos, 1963.

Mack, Peter. A History of Renaissance Rhetoric 1380-1620. Oxford: Oxford University Press, 2011. 
María Antonia del Niño Jesús, sor. Flor de santidad: la madre Castillo. Tunja: Academia Boyacense de Historia, 1993.

McKnight, Kathryn Joy. The Mystic of Tunja: The Writings of Madre Castillo 1671 1742. Massachusetts: University of Massachusetts Press, 1997.

Méndez Plancarte, Alfonso. "Un libro de Gómez Restrepo y una triple restitución a sor Juana". Ábside 7 (1941): 451-463.

Mendiola, Alfonso. Retórica, comunicación y realidad. La construcción retórica de las batallas en las crónicas de la conquista. México: Universidad Iberoamericana, 2003.

Moore, Charles B. "Fuentes y funciones de los excrementos a lo divino en Los afectos espirituales de la madre Castillo (1671-1742)". Anales de Literatura Hispanoamericana 40 (2011): 201-217.

Moore, Charles B. "Entre los animales y lo divino: el alma, el bestiario y el barroco en los Afectos espirituales de la madre Castillo (1672-1741)". Dieciocho 36, núm. 1 (2013): 79-98.

Morales, María Teresa. La madre Castillo, su espiritualidad y su estilo. Bogotá: Instituto Caro y Cuervo, 1968.

Morales, María Teresa. "Comparaciones y símbolos en la obra de la madre Castillo: algunas páginas de la obra La madre Castillo, su espiritualidad y su estilo". Boletín de la Academia Colombiana 22, núm. 91 (1972): 36-44.

Mújica, Elisa. Sor Francisca Josefa de Castillo. Bogotá: Procultura, 1991.

Nakládalová, Iveta. "Contemplar a Dios sin imágenes. La imagen en los tratados de meditación en la Primera Edad Moderna". Studia Aurea 9 (2015): 265294.

Otero Muñoz, Gustavo. "Santa Teresa y la madre Castillo". Revista de las Indias 14, núm. 43 (1942): 162-168.

Peña Díaz, Manuel. "Normas y transgresiones. La cultura escrita en el Siglo de Oro". En Grafías del imaginario. Representaciones culturales en España y América (siglos XVI-XVIII). Comp. de Carlos Alberto González y Enriqueta Vila Vilar, 120-129. México: FCE, 2003.

Plett, Heinrich. Enargeia in Classical Antiquity and the Early Modern Age. Leiden: Brill, 2012.

Porras, Ernesto. "Sor Juana Inés de la Cruz y sor Francisca Josefa de la Concepción: dos caminos humanos para conocer lo divino". En Memorias del Coloquio Internacional Sor Juana Inés de la Cruz y el Pensamiento Novohispano, 367-373. México: Instituto Mexiquense de Cultura, 1995. 
Quintiliano, Marco Fabio. Instituciones oratorias, t. II. Madrid: Perlado Páez y Compañía, 1916.

Rey Fajardo, José del. Catedráticos jesuitas de la Javeriana colonial. Bogotá: Centro Editorial Javeriano, 2002.

Rey Fajardo, José del. Biblioteca de escritores jesuitas neogranadinos. Bogotá: Pontificia Universidad Javeriana, 2006.

Rey Fajardo, José del. La república de las letras en la Venezuela colonial (la enseñanza de las humanidades en los colegios jesuíticos). Caracas: Academia Nacional de Historia, 2007.

Rey Fajardo, José del. Educadores, ascetas y empresarios. Los jesuitas en la Tunja colonial (1611-1767), t. I. Bogotá: Pontificia Universidad Javeriana, Academia Boyacense de Historia, 2010.

Rico Callado, Francisco Luis. "Conversión y persuasión en el barroco: propuestas para el estudio de las misiones interiores en la España postridentina". Studia Historica: Historia Moderna 24 (2002): 363-386.

Robledo, Ángela Inés. "Disociación múltiple y juegos narcisistas en Afectos y Su vida de la madre Castillo". Correo de los Andes 57 (1989): 34-50.

Robledo, Ángela Inés. "La pluralidad discursiva como mecanismo de afirmación personal en Su vida de Francisca Josefa de Castillo". En ¿Y las mujeres? Ensayos sobre literatura colombiana, 21-65. Medellín: Universidad de Antioquia, 1991.

Rodríguez de la Flor, Fernando. Teatro de la Memoria. Siete ensayos sobre mnemotécnica española de los siglos XVII y XVIII. Valladolid: Junta de Castilla y León, 1988.

Rodríguez de la Flor, Fernando. Emblemas. Lecturas de la imagen simbólica. Madrid: Alianza, 1995.

Regla, constituciones y ordenaciones de las religiosas de S. Clara, de la ciudad de S. Fee de Bogotá: en el nuevo Reyno de Granada: de las Indias de el Peru. Roma: Lucas Antonio Chracas, 1699.

Schlau, Stacey. "From Alienation to Consolation in Madre Castillo's Su Vida". En Women's Voices and the Politics of the Spanish Empire: From Convent Cell to Imperial Court. Ed. de Jennifer Eich, Jeanne Gillespie y Lucia Guzzi Harrison, 31-54. Nueva Orleáns: University Press of the South, 2008.

Steffanell, Alexander. El caso madre Castillo: discurso confesional hegemónico y canon en la literatura colombiana. Bogotá: Thomas de Quincey Editores, 2012. 
Stoichita, Víctor. El ojo místico. Pintura y visión religiosa en el Siglo de Oro español. Madrid: Alianza, 1995.

Toquica, Constanza. A falta de oro: linaje, crédito y salvación. El Real Convento de Santa Clara de Santafé de Bogotá. Siglos XVII y XVIII. Bogotá: Universidad Nacional de Colombia / ICANH, 2008.

Villa Leiva, Alberto. "La santa Teresa granadina, o la madre Josefa del Castillo". Revista Policía Nacional de Colombia 16, núm. 78 (1959): 61. \&g 